Problematika Keluarga dengan Pola Karir Ganda

\title{
PROBLEMATIKA KELUARGA DENGAN POLA KARIR GANDA (Studi Kasus di Wilayah Mangir, Sendangsari, Pajangan, Bantul, Yogyakarta)
}

\author{
Nur Endah Januarti ${ }^{1}$
}

\begin{abstract}
Problematic families with dual career path describes the life patterns of families with dual careers or families with a composition of husband and wife who are both working. Case studies conducted in the Territory Mangir, Sendangsari, Displays, Bantul, Yogyakarta. This study aims to: 1) Knowing the family background with dual career path to choose multiple career patterns in family life; 2) Knowing the various problems faced; 3) Knowing how to overcome various problems encountered.

The following research using qualitative methods. Research resource persons were family members along with a third party if the family has a maid or relatives who live together. Research subjects taken by purposive sampling. The process of data collection is done by semi-structured interviews, non-participatory observation, field recording, and documentation. Researchers used the instrument in the form of interview guidelines and guidelines for observation. Checking the validity of data using triangulation techniques. Techniques in data analysis is data reduction, data presentation, and conclusion.

The results showed that: 1) family background choose multiple career patterns in the family was at first a husband and wife are both working and the next because there is a principle or desire to get couples to work; 2) The problems that occur a variety of them ( a) not to participate in social activities, (b) the limited ability of parents to accompany the development of children's learning process, (c) unanticipated expenditures related to contributions to a celebration activities in the community and colleagues in the office, (d) no homework completion ladder well, (e) the rules of time to work all the time / not stabilized, ( $f$ ) communication eg for "relationship" husband and wife, (g) the crisis of confidence in their role of a mother, wife and a worker, ( $h$ ) terbenturnya work agenda in the workplace with other activities, (i) special assistance for children who cause the job not the maximum, (j) fatigue or stress on the solid work, (k) lack of parental control; 3) Efforts made or how to deal with various problems is (a) communication, (b) use the services of a third party, (c) one of the parties in, (d) ask for advice to the other party. Also found some of the findings in families with dual career path in this study are: (a) in a family with the dual career path job became one of the major factors considered in determining the amount ketururnan in the family (b) still attached placement of women at a subordinate under men.
\end{abstract}

Keywords: Family, Patterns, Career, Ganda, Problems.

\footnotetext{
${ }^{1}$ Mahasiswa Pasca Sarjana Sosiologi UGM, Alumni Pend. Sosiologi UNY
} 


\section{A. Pendahuluan}

Setiap masyarakat pasti akan dijumpai keluarga batih (nuclear family) yang merupakan kelompok sosial terkecil yang terdiri dari suami, istri beserta anak-anaknya. Keluarga batih juga disebut sebagai sebuah rumah tangga dan sebagai unit terkecil dalam masyarakat sebagai wadah proses pergaulan hidup. $^{2}$

Keluarga batih pada dasarnya memiliki fungsi sebagai unit sosial terkecil dalam masyarakat karena sebagai tempat bersosialisasi, mengatur hubungan seksual, mengatur hubungan ekonomi, dan memberikan perlindungan serta ketentraman bagi perkembangan jiwa. Keluarga sebagai bentuk kelompok sosial terkecil namun terpenting dalam suatu masyarakat. Terkecil karena sesuai dengan unit pembentukannya keluarga pada umumnya terdiri atas beberapa anggota yakni ayah, ibu dan anak yang memiliki peran dan fungsi berbeda-beda. Sedangkan terpenting karena dalam keluarga mengalami proses sosialisasi awal, pembentukan watak dan kepribadian sehingga membentuk individu yang mampu hidup dalam lingkup lebih luas yakni masyarakat.

Pada keluarga konvensional yang notabene sebuah struktur budaya masih sangat melekat dalam kehidupan masyarakat, ada konstruksi budaya yang melekat bahwasanya suami bertugas

\footnotetext{
2 Soerjono Soekanto, Sosiologi Keluarga, Jakarta: Rineka Cipta, 2004, hlm. 1.
}

mencari nafkah dan istri mengurus rumah tangga. Suami berlaku dalam sektor publik dan istri berlaku dalam sektor domestik.

Modernisasi yang saat ini terjadi berpengaruh pada lingkungan sosial budaya di sekitar keluarga. Seiring dengan perkembangan zaman, perkembangan pola pikir masyarakat serta semakin gencarnya perjuangan perlakuan kesetaraan gender dalam kehidupan masyarakat yang masih dirasakan ada ketimpangan terhadap kaum perempuan kemudian lambat laun perempuan pun mulai berjuang menempatkan posisinya dalam kancah publik. Baik dalam bidang ekonomi, pertahanan maupun politik dan bidang kehidupan yang lain. Adat dan konstruksi budaya yang semakin menempatkan perempuan pada posisi kurang terhitungkan mulai disetarakan. Hal ini tak lain karena kesadaran masyarakat bahwasanya kaum perempuan atau kemudian yang terdefinisikan menjadi istri dan ibu dalam keluarga pada masa sekarang ini bukan saatnya lagi untuk hanya berdiam diri di rumah. Bukan hal yang tabu lagi ketika wanita pun bekerja. Wanita pun menjadi partner suami dalam keluarga dalam mencari nafkah. Kehidupan rumah tangga dalam sektor ekonomi bukan hanya menjadi tanggung jawab satu pihak, melainkan menjadi tanggung jawab bersama.

Dengan tumbuhnya kesempatan bagi wanita bersuami untuk bekerja, pada pola kekeluargaan segera berubah dan muncul apa yang disebut sebagai 
karir ganda atau dualisme karir ${ }^{3}$. Banyak terjadinya karir ganda tidak hanya dalam keluarga menengah namun juga berkembang di antara keluarga-keluarga pekerja. Ketika suami dan istri dalam keluarga sama-sama memiliki karir atau pekerjaan tentunya dalam hal ini yang terpengaruh adalah pola kehidupan dan pola manajerial dari keluarga tersebut. Mulai dari pola pengasuhan anak, pola manajemen ekonomi keluarga, pola sosialisasi dalam keluarga dan sebagainya. Tentunya antara keluarga yang tidak berkarir ganda dan keluarga yang berkarir ganda memiliki perbedaan-perbedaan terhadap permasalahan yang dihadapi.

Asumsi yang muncul, antara keluarga dengan kondisi suami istri salah satu yang bekerja dan keluarga yang berkarir ganda akan memiliki perbedaan terhadap pola kehidupan keluarganya. Pertimbangan dalam hal ini adalah intensitas waktu dan efektivitas keterjangkauan pola keuangan dalam keluarga. Peran-peran seorang ibu atau ayah, dalam hal ini yang disoroti salah satu hal utama diantara keduanya tentunya akan berbeda. Ketika dalam keluarga seorang ayah saja yang bekerja atau seorang ibu saja yang bekerja dengan asumsi bahwa salah satu bertugas untuk bertanggungjawab minimal lebih intensif di rumah. Hal ini tentunya akan berbeda ketika kemudian keduanya sama-sama

\footnotetext{
3 Parker, dkk, Sosiologi Industri, Jakarta: Rineka Cipta, 1992, hlm. 74-75.
}

bekerja tentunya akan ada pengaruh terhadap kemungkinan pertama adalah tanggungjawab intensif di rumah berkurang atau munculnya pihak baru seperti pembantu rumah tangga yang bertugas untuk memenuhi kekurangan pemenuhan tanggungjawab peran orang tua dalam keluarga.

Kehidupan sebuah keluarga tentunya beraneka ragam dan memiliki karakter berbeda-beda. Senada dengan hal tersebut, masalah-masalah yang dihadapi atau adanya keputusan berkarir ganda dalam keluarga tentunya akan berbeda antara satu keluarga dengan keluarga yang lain. Karir seperti apa yang ditekuni orang tua, tipe atau cara manajemen dan pola menyiasati keberlangsungan kehidupan terhadap keluarga juga menjadi hal yang akan mempengaruhi adanya masalahmasalah yang dihadapi dan tentunya pemecahannya. Sejalan dengan itu menjadi penting adanya dalam keluarga untuk lebih menyepakati dan menyiasati terhadap keputusan dan kesepakatan yang akan diambil. Mangir adalah suatu kawasan wilayah di Desa Sendangsari, Kecamatan Pajangan, Kabupaten Bantul, Propinsi Yogyakarta. Lingkungan yang erat dengan cerita $\mathrm{Ki}$ Ageng Mangir Wonoboyo ini terbagi menjadi 3 kawasan secara administratif yakni Dusun Mangir Lor, Dusun Mangir Tengah dan Dusun Mangir Kidul. Lingkungan wilayah ini masih 
| Nur Endah Januarti

bersifat sederhana dengan karakteristiknya. Masyarakat perdesaan Mangir sedikit banyak telah terpengaruh oleh perubahan modernitas di berbagai bidang, namun karakter tradisional dan perdesaan masih cukup melekat di wilayah ini. Terbukti masih banyaknya upacara-upacara adat yang enggan untuk ditinggalkan karena kepercayaan masyarakat atau "orang tua" yang harus terus dilestarikan dan dianggap railok jika ditinggalkan. Seperti dicontohkan masih ada tradisi suran (suro), mitoni (tujuh bulan) dan lain sebagainya. Selain itu masyarakat juga masih banyak yang percaya pada mitos-mitos tentang hari baik sesuai neptu dan sebagainya apabila ingin menyelenggarakan suatu acara.

Dibalik masih melekatnya kepercayaan dan masyarakat yang tradisional, dalam hal ketimpangan gender sudah cukup mengalami pergeseran. Karena terbukti dengan adanya peran wanita di kancah publik baik untuk bekerja maupun berorganisasi. Suatu keadaan keluarga yang di dalamnya suami istri bekerja merupakan hal yang wajar dan justru menjadi dambaan. Entah apa pun itu pekerjaan terutama yang dilakukan oleh perempuan. Kiprah perempuan untuk mencari nafkah dalam berbagai bidang baik pekerjaan yang sifatnya di rumah atau di luar rumah. Pekerjaan di rumah misalnya pekerjaan seperti buruh pembuat emping belinjo, gula, usaha warung dan sebagainya. Pekerjaan di luar rumah misalnya
PNS, petani, pedagang, buruh pabrik, TKW dan sebagainya. Organisasi yang digawangi kaum perempuan pun sudah ada, seperti PKK, Posdaya, dan sebagainya.

Dari berbagai hal tersebut menjadi sebuah gambaran bahwa pada masa modern seperti ini keluarga yang di dalamnya terdiri minimal atas suami, istri serta anak menjadi sebuah tuntutan untuk dapat memenuhi kebutuhan ekonomi dan keberlangsungan hidup keluarga di tengah perubahan masyarakat. Sehingga keputusan suami istri untuk bekerja bukan menjadi hal yang tabu lagi dalam kebanyakan masyarakat. Salah satu diantaranya di masyarakat Mangir, Sendangsari, Pajangan, Bantul, Yogyakarta. Tentu saja kondisi sama-sama bekerja dalam sebuah keluarga juga akan berdampak dalam berbagai hal mengenai pola kelangsungan hidup keluarga. Selain mendukung kebutuhan keluarga secara finansial, namun terjadinya masalah-masalah menjadi satu hal yang tidak dapat lepas dari kehidupan.

Oleh karena itu, penelitian dilakukan untuk mampu mengetahui problematika yang terkait dengan masalah yang dihadapi dalam keluarga yang suami istri sama-sama bekerja (karir ganda) sehingga menjadi inspirasi bagi keluarga atau calon-calon pasangan yang akan memutuskan untuk membina keluarga. Selain itu juga mampu memahami bagaimana upaya yang dapat dilakukan untuk mampu mengatasi problematika yang dihadapi dalam keluarga berkarir ganda. 
| Problematika Keluarga dengan Pola Karir Ganda

\section{B. Kajian Pustaka}

\section{Tinjauan Keluarga}

Keluarga merupakan kelompok sosial kecil yang umumnya terdiri atas ayah, ibu dan anak yang memiliki hubungan sosial relatif tetap dan didasarkan atas ikatan darah, perkawinan atau adopsi Keluarga merupakan kelompok primer yang terpenting dalam masyarakat. Keluarga sebagai organisasi terkecil dalam masyarakat mempunyai perbedaan dari organisasi lainnya dalam masyarakat tersebut serta memiliki pengertian yang mendalam daripada organisasi yang lain. Salah satu perbedaan yang penting dilihat dari hubungan anggotanya yang bersifat gemeinschaft dan merupakan ciri-ciri kelompok primer antara lain:4

a. Mempunyai hubungan yang lebih intim

b. Kooperatif

c. Face to face

d. Masing-masing anggota memberlakukan anggota lainnya sebagai tujuan bukan sebagai alat untuk mencapai tujuan.

Sehingga

hubungan antaranggota dalam keluarga lebih bersifat pada hubungan interpersonal dan memiliki jaringan hubungan yang sangat intim. Masing-masing anggota keluarga memiliki intensitas hubungan satu sama lain.

\footnotetext{
4 S.T Vembriarto, Sosiologi Pendidikan, Yogyakarta: Yayasan Paramita, 1982, hlm. 36.
}

Adapun ciri-ciri keluarga
secara umum seperti yang
dikemukaan Mac Iver and Page
yakni 5:

a. Keluarga merupakan hubungan perkawinan

b. Berbentuk perkawinan atau susunan kelembagaan yang berkenaan dengan hubungan perkawinan yang sengaja dibentuk atau dipelihara

c. Suatu sistem tata nama termasuk perhitungan garis keturunan

d. Ketentuan-ketentuan ekonomi yang dibentuk oleh anggota-anggota kelompok yang mempunyai ketentuan khusus terhadap kebutuhankebutuhan ekonomi yang berkaitan dengan kemampuan untuk mempunyai keturunan dan membesarkan anak

e. Merupakan tempat tinggal bersama, rumah atau rumah tangga walau bagaimanapun tidak mungkin terpisah terhadap kelompok keluarga. Pada dasarnya keluarga mempunyai fungsi pokok yakni fungsi yang sulit dirubah atau digantikan oleh orang lain. Sedangkan fungsi lain atau fungsi sosial relatif lebih mudah berubah atau mengalami perubahan.

Adapun fungsi pokok keluarga ${ }^{6}$ antara lain :

a. Fungsi biologik

\footnotetext{
${ }^{5}$ Khairuddin, op.cit, hlm. 12.

${ }^{6}$ Ibid, hlm. 58-60.
} 
Nur Endah Januarti

$\begin{array}{lr}\begin{array}{l}\text { Merupakan } \\ \text { kelangsungan }\end{array} & \begin{array}{r}\text { dasar } \\ \text { hidup }\end{array} \\ \text { masyarakat. } & \text { Keluarga } \\ \text { merupakan tempat lahirnya } & \text { lak } \\ \text { anak-anak dengan } & \text { fungsi } \\ \text { biologik orang tua sebagai } & \text { seban } \\ \text { penerus keturunan atau } \\ \text { melahirkan anak. }\end{array}$

b. Fungsi afeksi

Hubungan ini timbul akibat hubungan cinta kasih yang menjadi dasar perkawinan. Dari hubungan ini timbullah rasa persaudaraan, persahabatan, kebiasaan identifikasi, persamaan pandangan mengenai nilainilai. Dasar cinta kasih dan hubungan afeksi merupakan faktor penting bagi perkembangan anak.

c. Fungsi sosialisasi

Fungsi ini menunjuk pada peranan keluarga dalam membentuk kepribadian anak. Melalui interaksi sosial dalam keluarga tersebut anak mempelajari pola-pola tingkah laku, sikap, keyakinan, cinta dan nilai-nilai dalam masyarakat dalam rangka perkembangan

kepribadiannya.

\section{Tinjauan Keluarga dan Perubahan Sosial}

Keluarga merupakan bagian integral dari sebuah masyarakat. Status pekerjaan dan kedudukan anggota keluarga pada kelompok lain akan membuat anggota keluarga jauh dari keintiman keluarga. Berkembangnya kebudayaan materi, tingkat penemuan dan inovasi teknologi, perbaikan fasilitas transportasi dan komunikasi serta meluasnya industrialisasi dan urbanisasi merupakan pendorong perubahan keluarga. Dalam kombinasinya faktor ini telah memperlemah pola kehidupan keluarga yang telah diterima sebelumnya.

Di luar hubungan interpersonal anggota keluarga, pengaruh mempengaruhi dari faktor ekonomi, sosial, politik, teknologi, dan filsafat telah menimbulkan sikap dan norma serta nilai baru dalam hubungan keluarga dan hubungannya terhadap lembaga lainnya. Ekonomi rumah tangga dan desa telah berubah menjadi sistem pabrik kota. Bertambah pula pengertian motivasi tingkah laku manusia dan merubah pendangan tradisional terhadap fungsi perkawinan serta kepribadian manusia. Dari semua itu filsafat hedonistis telah menjadi orientasi kebahagiaan keluarga serta selanjutnya dapat merubah struktur dan fungsi keluarga7.

\section{Tinjauan Pola Karir Ganda}

Karir ganda atau dualisme karir terjadi apabila suami maupun istri sama-sama bekerja dan mengurus rumah tangga secara bersama pula 8 . Di dalam hubungannya dengan posisi masing-masing, setiap pasangan suami istri memiliki cara yang berbeda di dalam mengatur peranannya dalam pekerjaan dan rumah tangga. Wanita yang bekerja secara part timer umumnya menganggap bahwa pekerjaan

\footnotetext{
${ }^{7}$ Khairuddin, op.cit, hlm. 107.

8 Parker, dkk, Sosiologi Industri, Jakarta: Rineka Cipta, 1992, hlm. 75.
} 
merupakan hobi dan menduduki prioritas kedua di bawah kepentingan keluarga. Namun dalam keluarga dualisme karir, suami istri bekerja tidak hanya sekedar mencari nafkah, yang sama pula dalam pengambilan keputusan serta berbagai aktivitas dalam keluarga ${ }^{9}$.

Karir ganda banyak terjadi di kalangan keluarga kelas menengah, tetapi juga berkembang diantara keluarga-keluarga kelas pekerja. Mungkin pandangan setiap wanita terhadap rumahtangga bermacammacam tergantung pada lingkungan sosialnya.

Dalam buku berjudul Bila Suami Istri Bekerja: The Two Career Marriage karya G Rowatt dkk disebutkan beberapa hal yang menyatakan sebab keluarga memilih pola karir ganda dengan memandang manfaat yang dapat diperoleh diantaranya ${ }^{10}$ :

a. Untuk mendapatkan keuntungan finansial

Keuntungan dari dua sumber pendapatan untuk menopang kebutuhan keluarga maupun pribadi telah menarik banyak istri atau wanita dalam keluarga untuk turut bekerja. keinginan untuk bebas dari himpitan pengeluaran bulanan yang semakin membengkak, inflasi tahunan yang semakin meningkat, serta tawaran pekerjaan di berbagai media massa atau lowongan pekerjaan

\footnotetext{
${ }^{9}$ Ibid, hlm. 75-76.

${ }^{10}$ G. Rowatt, dkk, Bila Suami Istri Bekerja: The Two Career Marriage, Yogyakarta: Kanisius, 1990, hlm. 29-43.
}

pemerintah mendorong para pasangan segala usia ke dalam karir ganda. Bagi beberapa pasangan, mendapatkan dua pendapatan merupakan satu-satunya pilihan. Perolehan finansial dapat memberikan kesempatan bagi suami untuk melanjutkan pendidikannya begitu pula istri. Cukup banyak istri yang bekerja agar suami mereka dapat menyelesaikan pendidikannya.

Para pasangan yang baru awal menikah atau belum begitu lama berumah tangga keduanya sama-sama bekerja agar dapat memuhi kebutuhan rumah tangga seperti pembelian perlengkapan, rumah atau peralatan tertentu yang diinginkan. Pada suami istri yang telah mencapai usia pertengahan keuntungan ekonomis berkat kerja ganda akan berguna untuk memenuhi kebutuhan-kebutuhan yang mulai berubah seperti biaya hidup atau pendidikan anak yang semakin besar, biaya kebutuhan dan selera rekreasi yang semakin berkembang dan sebagainya. Selain itu keuntungan finansial memungkinkan keinginan suami istri untuk menabung demi hari tua mereka.

b. Sebagai kekuatan keluarga Keluarga mengalami perkembangan secara emosional bila kedua orang tua bekerja. walaupun stress akan meningkat tetapi tidak perlu menjadi desdruktif justru akan membuatn semakin produktif. Menyangkut kepentingan anak, penghasilan 
keluarga diperuntukkan bagi perkembangan anak. Meskipun seorang bayi atau anak membutuhkan pendekatan kasih sayang orang tua, namun anak usia prasekolah atau sekolah dasar yang kedua orang tuanya sama-sama bekerja akan mengalami pula perkembangan emosional dalam kesempatan bersosialisasi di tempat perawatan anak. Pengalaman anak akan lebih luas daripada sendirian di rumah bersama ibunya. Anakanak yang turut terlibat dalam pekerjaan rutin rumah tangga bila kedua orang tua bekerja akan memiliki pandangan dan sikap sehat tentang kerja serta mempelajari ketrampilanketerampilan yang kelak berguna untuk hidup mereka.

c. Wujud Kebebasan

Kebebasan pribadi yang diperoleh oleh para pasangan karir ganda merupakan perkembangan kebebasan yang paling utama. Baik suami maupun istri memperoleh keuntungan pencapaian ini. Situasi istri yang bekerja memungkinkan para suami juga untuk turut menjadi 'pengatur rumah tangga' atau secara bersama-sama.

Interaksi sosial orang dewasa sewaktu berada di tempat kerja merupakan hasil kebebasan yang kedua. Banyak istri atau ibu rumah tangga yang menjadi sangat jemu karena sangat kurang diskusi dan interaksi. Terbebas dari pengkotakan peran menjadi sebuah kebebasan pula pada suami istri yang bekerja. Batas peran yang justru menentukan apa yang layak dan pantas untuk dikerjakan oleh pria dan apa yang pantas dikerjakan oleh wanita.

Masing-masing partner tumbuh menjadi pekerja yang serba bisa. Hal ini memandang wanita tradisioanl yang dilarang memasuki pentas kerja , maka dengan kebebasan wanita yang bekerja akan ada kesempatan untuk dapat menduduki suatu jabatan.

Beberapa kunci masalah pada hakikatnya bukan masalah ekonomi dapat digunakan sebagai kunci ke arah pemahaman tentang keluarga dengan karir ganda. Komitmen yang diciptakan merupakan faktor utama para pasangan karir ganda dalam menghadapi permasalahan di antara mereka. Komitmen orang tua kepada anak memperkokoh kegigihan dalam memecahkan problema perawatan dan pemeliharaan anak. Komitmen keluarga pada masyarakat luas memberikan pandangan tentang tata nilai dan arah tujuan. Kebebasan juga merupakan salah satu faktor yang menentukan kehidupan keluarga berkarier ganda. Para istri memiliki kebebasan untuk menjadi ibu rumah tangga saja atau mengikatkan diri dengan bekerja untuk mendapatkan penghasilan serta suami menjadi anggota keluarga secara emosional serta bukan hanya mendukung kegiatan ekonomi. Anak-anak memerlukan kebebasan untuk menjadi orangorang yang berkepribadian dan memerlukan orangtua yang mau mengabdikan diri untuk tujuan tersebut. 11

${ }^{11}$ Ibid, hlm. 25. 


\section{Tinjauan Problema Karir Ganda dalam Keluarga}

Problema, problematika atau problematik dalam Kamus Umum Bahasa Indonesia dinyatakan sebagai permaslaahan atau hal-hal yang masih menjadi masalah ${ }^{12}$. Masalah merupakan sesuatu yang ada ketika seorang individu menjadi sadar akan perbedaan yang signifikan antara apa yang sebenarnya dan apa yang diinginkan ${ }^{13}$.

Di dalam perkembangan yang berkaitan dengan aktualisasi kehidupan orang dewasa, tidak pernah terlepas dari problematika kehidupan yang perlu mereka hadapi dengan sebaik-baiknya. Pada umumnya problematika hidup orang dewasa bersumber dari kurang berhasilnya menguasai beberapa atau sebagian tugas perkembangan yang penting. Menurut Harlock, ada tugas-tugas individu meliputi harapan-harapan yang diperolehnya seperti pekerjaan, memilih pasangan hidup, membentuk dan mengolah keluarga, bertanggungjawab sebagai warga negara dan sebagainya. ${ }^{14}$

\footnotetext{
${ }^{12}$ J.S Badudu dan Sutan Muhammad Zain, Kamus Umum Bahasa Indonesia, Jakarta: Pustaka Sinar Harapan, 1996, hlm. 1089.

${ }^{13}$ Wikipedia, Kata kunci: problem, 2010, Tersedia pada

http://translate.googleusercontent.com/2010/24/ wikipedia-problem/. Diakses tanggal 29 Januari 2010.

${ }^{14} \mathrm{Nn}$, Problematika hidup orang dewasa, 2010, Tersedia pada http://www.google.com/2010/problematika -
}

Individu dalam masyarakat memiliki tugas-tugas yang sesuai dengan perannya dalam masyarakat. Untuk menjalankan tugasnya tersebut tentunya tidak lepas dari berbagai rintangan yang dihadapi individu. Rintangan tersebut kemudian menjadi satu problematika tersendiri dalam kehidupan perkembangan individu. Ada beberapa problematika yang dapat dialami individu dalam perkembangan kehidupannya yakni karena faktor fisik, keagamaan, sosial, peran seks, perkerjaan, dan perkawinan. 15

a. Problematika fisik

b. Problematika keagamaaan

c. Problematika sosial

d. Problematika peran seks

e. Problematika pekerjaan

f. Problematika perkawinan

Seiring tumbuhnya kesempatan bagi wanita bersuami untuk bekerja di zaman modern, pola kekeluargaan juga mengalami perubahan dan muncullah yang disebut sebagai dualisme karir atau karir ganda. Dualisme karir atau karir ganda terjadi bila suami istri sama-sama bekerja dan mengurus rumahtangga secara bersama pula. Di dalam hubungannya dengan posisi masing-masing setiap pasangan suami istri memiliki cara yang berbeda dalam mengatur peranannya dalam pekerjaan dan rumah tangga.

problematika hidup orang dewasa/. Diakses pada tanggal 29 Januari 2010

${ }^{15}$ Ibid. 
Disebutkan dalam buku "Bila Suami Istri Bekerja" bahwa adanya sumber kerawanan tertentu yang dialami oleh suami istri yang samasama bekerja. Kehadiran anak akan menambah panjang daftar kesulitan. Daerah ketegangan tersebut mencakup beberapa kesulitan:

a. Prioritas terhadap salah satu pekerjaan.

Hal ini melihat kenyataan terhadap pekerjaan salah satu pihak yang dianggap lebih menguntungkan dan tidak merepotkan sehingga ada pertimbangan-pertimbangan yang justru menimbulkan kecenderungan memprioritaskan pekerjaan salah satu pihak.

b. Adanya rasa kurang puas terhadap tugas atau kewajiban rumah tangga salah satu pihak.

Hal ini terjadi misalnya ketika makanan belum siap atau pakaian belum diseterika dan sebagainya yang disebabkan karena belum sempat dilakukan karena aktivitas pekerjaan kantor. Umumnya kemudian hal ini dibebankan pada wanita dalam rumah tangga sehingga suami merasa bahwa istri tidak dapat melayani dengan baik dan sebagainya. Sehingga kadangkadang tugas-tugas tersebut menjadi pemicu ketegangan dalam keluarga.

c. Keluhan terhadap pekerjaanpekerjaan yang menumpuk dan belum diselesaikan.

Waktu yang merupakan sebuah faktor dalam permasalahan ini. Setiap menja]elang malam ketika keluarga dijejali oleh tugas rumah tangga yang belum diselesaikan sehingga menambah panjang daftar "tunggakan". Semakin banyak pekerjaan rumah tangga yang tidak dapat diselesaikan.

d. Munculnya stres karena tidak dapat melakukan kebiasaan tertentu.

Istirahat, santai, rekreasi hilang dari kehidupan karena terdesak oleh pekerjaan. Hal lain dans erupa menyangkut masalah spiritual. Kebiasaan-kebiasaan ibadah secara bersama-sama untuk kesegaran jiwa menjadi jarang dilakukan. Muncul perasaan bahwa hidup menjadi jauh dari sumber kekuatan sebagai makhluk religius.

e. Stres karena isolasi dari temanteman.

Hal ini dapat dilihat ketika dalam keluarga yang sama-sama bekerja memiliki ruang sempit untuk dapat mengadakan acara bersama rekan-rekan sekadar untuk menjamu atau sebaliknya menghadiri acara tertentu yang diadakan oleh rekan.

f. Stres karena masalah perawatan anak dan tuntutan keluarga.

Masalah ini menyangkut bagaimana perawatan dan pengasuhan terhadap anak secara baik disamping kesibukan bekerja orang tua. Sehingga kadang kala menimbulkan ketegangan terhadap tugas-tugas tertentu yang harus dilakukan. Alternatif pengasuh anak pun menjadi solusi yang diterapkan beberapa keluarga agar anak tetap mendapat pengasuhan yang cukup baik. 
| Problematika Keluarga dengan Pola Karir Ganda

\section{Tinjauan tentang Uang}

Kekhususan fungsionalitas, rasionalitas, dan impersonalitas dalam hubungan sosial masa kini disimbolkan dan dipermudah dengan uang. Sebagai suatu ukuran nilai yang obyektif dan baku, uang memungkinkan produk-produk atau jasa yang benar-benar tidak serupa dibandingkan satu sama lain untuk menentukan nilai relatifnya sama dengan pertukaran. Hal inilah yang kemudian menyebabkan individu mau untuk melakukan atau membayar dengan apa yang dimilikinya baik berupa jasa maupun pikiran karena begitu pentingnya uang dalam kehidupan apalagi masa sekarang ini.

Uang kemudian mampu mempertinggi kebebasan individu. Dalam hal ini pengaruh sosiologisnya berupa keterlibatan kelompok ganda. Orang dengan banyak uang dapat mengambil keuntungan dari kecenderungan dengan apa saja yang mereka mau. Gaya hidup individu tidak terlalu banyak ditentukan oleh kebiasaan dan tradisi, seperti yang ditentukan oleh sumber-sumber keuangan yang mereka miliki untuk memenuhi kebutuhan yang sudah ditentukan tersebut. Singkatnya, bentuk sosial dominan dalam kehidupan modern sangat berbeda dengan kehidupan sebelumnya. Sebagian dari perbedaan tersebut berhubungan dengan semakin bertambah banyaknya corak kehidupan modern. ${ }^{16}$

\section{Tinjauan tentang Feminisme} Melalui perkembangan proses dialektis terhadap kesetaraan gender, memunculkan asumsi bahwa peran-peran publik atau domestik bukan lagi menjadi keharusan menjadi salah satu tanggung jawab satu pihak dalam anggota keluarga. Melainkan ada konsep kesepakatan yang dibangun dalam keluarga. Tidak ada unsur pemaksaan dan lebih dipertimbangkan dari kapasitas sosialnya. Ideologi patriarkhi yang masih menempatkan laki-laki pada posisi dominan dalam kapasitas baik ekonomi, politik dan sosial serta dalam kancah publik digulirkan dalam konsep bahwa perempuan pun mampu untuk mendapatkan peran-peran tersebut.

Melalui feminisme juga dikemukakan terhadap munculnya gerakan yang kemudian ingin menempatkan posisi kesetaraan gender dimana wanita kemudian menyatakan dirinya dalam feminisme sosialis yang mengakui bahwa penindasan perempuan tidak hanya terjadi pada tatanan pertentangan kelas, melainkan sistem patriarkhi. Masyarakat yang telah terisolasi oleh budaya patriarkhi yang mengutamakan laki-laki. Sehingga pentingnya membantu kesadaran kelas dan meningkatkan kualitas dan kuantitas keterlibatan kaum

\footnotetext{
${ }^{16}$ Doyle Paul Johnson, Teori Sosiologi Klasik dan Modern Jilid I, Jakarta: Gramedia, 1988, hlm. 284-285.
} 
perempuan dalam pengambilan keputusan. ${ }^{17}$

Kehidupan sekarang ini perempuan pun bersama-sama suami dalam keluarga terjun dalam karir dan kancah publik, serta ada kondisi yang bukan tidak mungkin justru laki-laki yang berada dalam sektor domestik. Pengaruhnya tentu dalam keluarga. Bagaimana kemudian peran-peran vital mereka dalam keluarga tetap terpenuhi dan kemudian menyangkut masalah yang dihadapi tentunya akan semakin beragam.

\section{Tinjauan tentang Konflik}

Dalam Kamus Besar Bahasa Indonesia, konflik didefinisikan sebagai sebuah pertengkaran, perselisihan, benturan ${ }^{18}$. Tentunya hal ini ketika dilihat dalam sebuah perspektif teori didefinisikan dalam beberapa pengertian oleh beberapa tokoh. George Simmel dan Max Weber tokoh pada abad ke-19 menyatakan bahwa konflik atau gejala konflik merupakan suatu gejala dalam masyarakat yang tidak dapat dihindarkan, namun justru memainkan peran positif dalam mempertahankan masyarakat dan memupuk rasa persatuan ${ }^{19}$.

Lewis A Cooser mendefinisikan konflik sebagai sebuah perselisihan mengenai nilainilai atau tuntutan-tuntutan berkenaan dengan status, kuasa dan sumber-sumber kekayaan yang

\footnotetext{
${ }^{17}$ Farida Hanum, Diktat Mata Kuliah: Sosiologi Gender, Yogyakarta: Universitas Negeri Yogyakarta, 2007, hlm.16.

${ }^{18}$ J.S Badudu dan Sutan Muhammad Zain, op.cit, hlm. 711.

${ }^{19}$ K.J Veeger, Realitas Sosial, Jakarta: Gramedia, 1986, hlm. 210.
}

penyediaannya tidak mencukupi di mana pihak-pihak yang sedang berselisih tidak hanya bermaksud untuk memperoleh barang yang diinginkan melainkan juga memojokkan, merugikan atau menghancurkan lawan mereka. Konflik dapat berlangsung antar individu dengan individu, antar kolektivitas (kumpulan) atau individu dengan kolektivitas. 20

Pandangan lain tentang konflik adalah pandangan Dahrendorf yang meletakkan sebuah teori konflik dalam masyarakat sebagai sebuah proses yang terjadi di antara masyarakat yang mengalami proses perubahan sosial yang terdiri atas berbagai unsur atas dasar paksaan yang dikenakan oleh segelintir anggota atas anggota lain. ${ }^{21}$

Sebagai sebuah sistem, tentunya masyarakat memiliki sejumlah elemen fungsional yang ada di dalamnya. Elemen-elemen tersebut akan saling terkait baik dalam masyarakat secara sederhana maupun kompleks. Ketika ada disfungsional dalam elemen-elemen tersebut akan mengakibatkan terjadinya konflik baik bersifat coercion (paksaan) maupun bukan paksaan. Hal ini kemudian akan menentukan keberlangsungan proses kehidupan dalam sebuah masyarakat tersebut.

\section{Tinjauan tentang Tindakan Sosial}

Weber sangat tertarik pada masalah sosiologis yang luas mengenai struktur sosial dan

\footnotetext{
${ }^{20}$ Ibid, hlm. 211.

${ }^{21}$ Ibid, hlm. 213-214.
} 
| Problematika Keluarga dengan Pola Karir Ganda

kebudayaan, tetapi ia melihat bahwa kenyataan sosial secara mendasar terdiri dari individuindividu dan tindakan sosialnya yang berarti. Kenyataan sosial tersebut berasal dari motivasi individu dan tindakan sosial (verstehen). Rasionalitas merupakan konsep dasar yang digunakan Weber dalam klasifikasi mengenai tipe-tipe tindakan sosial. Aspek pemikiran Weber yang mencerminkan tradisi idealis adalah penekanan pada verstehen (pemahaman subyektif) sebagai metode untuk memperoleh pemahaman yang valid mengenai arti subyektif tindakan sosial individu. ${ }^{22}$

Pembedaan pokok yang diberikan adalah tindakan rasional dan nonrasional. Tindakan rasional berhubungan dengan perimbangan sadar dan pilihan bahwa tindakan itu dinyatakan. Tindakan rasional instrumental menjadi satu jenis tindakan berdasarkan pertimbangan rasional yang menyangkut pilihan sadar dan berhubungan dengan tujuan tindakan tersebut serta alat yang dipergunakan untuk mencapainya. Individu dilihat memiliki macam-macam tujuan yang mungkin diinginkannya dan atas dasar kriterium untuk menentukan satu pilihan di antara tujuan-tujuan tersebut. Tindakan sosial rasional berorientasi nilai menjadi jenis berikutnya dalam tindakan sosial. Tindakan ini

\footnotetext{
${ }^{22}$ Doyle Paul Johnson, op.cit, hlm. 214.
}

menyatakan bahwa alat-alat mencapai tujuan hanya merupakan obyek pertimbangan dan perhitungan yang sadar, tujuannya sudah ada dalam hubungannya dengan nilai-nilai individu yang bersifat absolut atau merupakan nilai akhir baginya. Nilai-nilai akhir bersifat nonrasional dalam hal seseorang tidak dapat memperhitungkan secara obyektif mengenai tujuan mana yang harus dipilih. Kemudian ada tindakan tradisional sebagai sebuah tindakan sosial yang bersifat nonrasional. Tindakan ini melihat ketika individu memperlihatkan perilaku karena kebiasaan, tanpa refleksi yang sadar atau perencanaan. Tipe tindakan sosial yang terakhir adalah tindakan afektif yang didominasi oleh perasaan atau emosi tanpa refleksi intelektual atau perencanaan yang sadar. ${ }^{23}$

9. Tinjauan tentang Sistem dan Struktural Fungsional.

Berawal dari konsep sistem sosial yang berasal dari aplikasi aksi sosial masyarakat sebagai unit tenaga masyarakat yang disusun dan aksi sebagai sebuah sistem. Sistem sosial dipahami sebagai keseluruhan susunan interaksi seseorang yang memotivasi kecenderungan dan membawa elemen dalam suatu peranan. ${ }^{24}$ Tiap-tiap sistem sosial terdiri dari pola perilaku tertentu yang mempunyai suatu struktur dalam

\footnotetext{
${ }^{23}$ Ibid, hlm. 220-221.

${ }^{24}$ Wardi Bachtiar, Sosiologi Klasik dari Comte hingga Parsons, Bandung: Remaja Rosdakarya, hlm. 351-353.
} 
dua arti yakni relasi-relasi sendiri antara orang yang bersifat agak mantap dan tidak cepat berubah serta memiliki corak atau bentuk yang relative tetap pula. ${ }^{25}$

Tiap sistem sosial mulai dari negara besar sampai keluarga batih menghadapi empat masalah yang perlu ditanggulangi agar tidak lenyap. Dikatakan Parsons sebagai empat imperatif prasyarat supaya sebuah keseimbangan sistem dapat dijamin yakni adaptasi (adaptation), kemungkinan mencapai tujuan (goal), integrasi anggota-anggotanya (Integration), dan kemampuan mempertahankan identitasnya terhadap kegoncangan dan ketegangan yang timbul dari dalam (latency). Sehingga konsep sistem mengartikan adanya antarhubungan dan kesalingketergantungan. Secara konkret hal ini berarti tiap struktur saling menerima dan memberi pengkhususan masing-masing. Sehingga suatu gerak tukarmenukar keempat output tersebut saling mempengaruhi terhadap fungsi berlangsungnya di dalam setiap sistem sosial antar setiap subsistemnya. ${ }^{26}$ Inilah sebagai sebuah fungsionalsme Parsons yang diakibatkan karena elemen atau struktur dalam sebuah sistem saling memberikan fungsi dan saling mempengaruhi secara fungsional.

\section{Metode Penelitian}

\section{Pendekatan Penelitian}

Dalam penelitian mengenai problematika keluarga berkarir

\footnotetext{
${ }^{25}$ K.J Veeger, op.cit, hlm. 202.

${ }^{26}$ Ibid, hlm. 207-209.
}

ganda diperlukan pendekatan penelitian yang mampu menelaah fenomena berupa kejadian, persepsi, motivasi, tindakan dan lain sebagainya untuk kemudian dideskripsikan dalam data berupa kalimat atau kata-kata. Sehingga Berdasarkan hal tersebut maka penelitian ini menggunakan pendekatan secara kualitatif deskriptif.

Menurut Bogdan dan Taylor, penelitian kualitatif didefinisikan sebagai sebuah prosedur penelitian yang menghasilkan data deskriptif berupa kata-kata tertulis atau lisan dari orang-orang dan perilaku yang dapat diamati 27 . Sehingga dalam hal ini data-data tertulis diperoleh dari anggota keluarga yang diteliti dalam kombinasi kesatuan keluarga yang mengalami dualisme karir tersebut.

Penelitian kualitatif juga merupakan sebuah penelitian yang bermaksud untuk memahami fenomena tentang apa yang dialami oleh subyek penelitian misalnya perilaku, persepsi, motivasi, tindakan dan lain-lain secara holistik dan dengan cara deskripsi dalam bentuk kata-kata dan bahasa, pada suatu konteks khusus yang alamiah dan dengan memanfaatkan berbagai metode alamiah ${ }^{28}$. Ada berbagai macam kejadian yang dialami oleh anggota keluarga yang merupakan sumber data yang dapat dijadikan bahan penelitian. Sehingga berbagai macam kejadian tersebut ditelaah atau dipahami

27 Lexy Moleong, Metodologi Penelitian Kualitatif, Bandung: Remaja Rosda Karya, 2005. hlm. 4.

${ }^{28}$ Ibid.hlm.6. 
peneliti sebagai satu alur kejadian yang mampu mendefinisikan terhadap data yang dikaji.

Sedangkan secara deskriptif (descriptive research) dalam hal ini merupakan sebuah pendekatan dengan mengeksplorasi dan klarifikasi mengenai sebuah fenomena atau kenyataan sosial, dengan jalan mendeskripsikan sejumlah variabel yang berkenaan dengan masalah atau unit yang diteliti. Jenis penelitian ini tidak sampai mempersoalkan jalinan hubungan antarvariabel yang ada, tidak untuk menarik generasi yang menjelaskan variabel yang menyebabkan suatu gejala atau kenyataan sosial. Sehingga dalam penelitian deskriptif tidak menggunakan dan melakukan pengujian hipotesis. ${ }^{29}$

Penelitian mengenai problematika keluarga berkarir ganda ini secara kualitatif deskriptif akan mendekatkan pada hasil kajian berupa berbagai macam kejadian yang dialami keluarga kemudian melalui kejadian tersebut secara deskriptif dapat didefinisikan sebagai sebuah eksplorasi atas fenomena atau kenyataan sosial tertentu yang dialami keluarga.

\section{Lokasi dan Waktu Penelitian}

Penelitian ini dilakukan di Wilayah Mangir, Sendangsari, Pajangan, Bantul, Yogyakarta dengan pelaksanaan penelitian selama kurang lebih 2 bulan yaitu pertengahan bulan Maret sampai

\footnotetext{
${ }^{29}$ Sanapiah, Faisal, Format-format Penelitian Sosial, Jakarta: Raja Grafindo Persada, 2005, hlm. 20 .
}

dengan pertengahan bulan Mei 2010 terhitung sejak diselesaikannya proposal ini.

\section{Sumber dan Jenis Data}

Sumber data terdiri atas beberapa data yang diperoleh peneliti melalui teknik pengumpulan data. Sumber data yang digunakan dalam penelitian ini yaitu:

a. Sumber data primer

Merupakan data yang diperoleh dengan cara menggali sumber asli secara langsung melalui responden. Perolehan data melalui wawancara atau pengamatan langsung di lapangan dengan informan yang dipilih dan memiliki kemampuan yang dapat dipercaya untuk menghasilkan data yang mantap dan benar.

Sumber data primer dalam penelitian ini merupakan anggota dari masing-masing keluarga atau pelaku utama dalam pola karir ganda yakni ayah dan ibu.

b. Sumber data sekunder

Merupakan sumber tidak langsung yang mampu memberikan data tambahan serta penguatan terhadap data penelitian. Sumber data sekunder adalah anak serta ketika keluarga memiliki pihak ketiga yang terlibat maka pihak ketiga menjadi pendukung atau sumber data sekunder. Selain itu melalui dokumentasi, studi kepustakaan, buku, majalah dan koran yang berhubungan dengan obyek yang diteliti juga menjadi sumber data sekunder yang dapat digunakan. 
Jenis data dalam penelitian ini yang dikumpulkan berupa katakata atau gambar, bukan angka seperti dalam penelitian kuantitatif. Data tersebut dapat meliputi transkrip interview, catatan lapangan, fotografi, videotape, dokumen personal, memo dan catatan resmi lainnya. 30

Secara kontekstual dalam penelitian ini menggunakan data deskriptif pula yakni berupa katakata atau gambar yang diperoleh melalui hasil wawancara. Peneliti juga memiliki catatan lapangan, foto dan sumber yang lain.

\section{Penentuan Subjek Penelitian dan Akses Penelitian}

Penentuan subjek dalam penelitian kualitatif adalah mementukan subjek-subjek penelitian yang dijadikan informan sehingga mendapatkan data hasil penelitian yang dapat disajikan secara umum.

Sehingga dalam suatu penelitian kualitatif ini penentuan subjek yang digunakan adalah dengan teknik sampel bertujuan (pusposive sample). Adapun teknik sampel bertujuan dilakukan dengan cara mengambil subjek bukan didasarkan atas strata, random atau daerah tapi didasarkan atas adanya tujuan tertentu ${ }^{31}$. Teknik ini dilakukan karena ada beberapa pertimbangan dengan syarat yang harus dipenuhi:

\footnotetext{
30 Asmadi Alsa, Pendekatan Kualitatif Kuantitatif serta Kombinasinya dalam Penelitian Psikologi, Yogyakarta: Pustaka Pelajar Offset, 2003, hlm. 40.

31 Suharsimi, Arikunto, Prosedur Penelitian Suatu Pendekatan Praktis, Jakarta: Rineka Cipta, 1993, hlm. 113.
}

a. Pengambilan sampel harus didasarkan atas ciri-ciri, sifatsifat atau karakteristik tertentu, yang merupakan cirri pokok populasi

b. Subyek yang diambil sebagai sampel benar-benar merupakan subyek yang paling banyak mengandung ciri-ciri yang terdapat dalam populasi (key subjects)

c. Penentuan karakteristik populasi dilakukan secara cermat dalam studi pendahuluan. ${ }^{32}$

Secara operasional melalui penelitian ini kriteria subjek secara umum adalah keluarga dengan jumlah anggota keluarga terdiri atas ayah, ibu, dan anak. Keluarga tersebut merupakan keluarga yang berpola karir ganda atau dikatakan ayah dan ibunya masing-masing memiliki pekerjaan di sektor publik. Kemudian dengan purposive sampling ditarik beberapa dari keluarga tersebut untuk dijadikan subjek penelitian. Adapun tujuan dari penarikan subjek penelitian tersebut adalah dengan menitikberatkan pada keluarga dengan pola karir ganda dengan problematika kompleks yang dialaminya. Sehingga akan diperoleh subjek yang sesuai dengan tujuan penelitian.

Akses

penelitian mengetengahkan proses peneliti mampu mendapatkan data yang dijadikan sebagai sumber penelitian. Mulai dari proses observasi awal mencari beberapa keluarga yang sesuai dengan kriteria dan sekiranya

32 ibid 
| Problematika Keluarga dengan Pola Karir Ganda

akan digunakan sebagai subjek penelitian.

Kemudian mempersiapkan berbagai macam kelengkapan prosedural administrasi seperti penyusunan proposal, seminar proposal kemudian melakukan proses penelitian.

Dalam penggalian data mengenai demografi atau keadaan penduduk di Mangir tentunya membutuhkan proses izin dari badan terkait secara resmi. Kemudian untuk penelitian kepada responden peneliti cenderung pada proses pendekatan personal dalam melakukan proses penelitian terhadap objek penelitian. Proses ini perlu dibangun agar objek peneliti bersedia secara alami melakukan proses yang diamati oleh peneliti.

\section{Teknik Pengumpulan Data}

Dalam penelitian ini menggunakan beberapa teknik pengumpulan data yakni observasi (pengamatan), interview (wawancara) dan dokumentasi.
a. Observasi (pengamatan)
b. Interview (wawancara)
c. Dokumentasi
d. Catatan Lapangan

\section{Instrumen Penelitian}

Instrumen merupakan alat pada waktu peneliti menggunakan suatu metode ${ }^{33}$. Penelitian ini menggunakan metode observasi, wawancara dan dokumentasi sehingga instrument yang dibutuhkan adalah pedoman

\footnotetext{
${ }^{33}$ Suharsimi Arikunto, op.cit, hlm. 121.
}

observasi, pedoman wawancara, recorder, kamera serta alat tulis.

Selain itu peneliti dalam penelitian ini juga merupakan instrumen yang langsung melaksanakan penelitian. Dalam penelitian kualitatif peneliti memiliki kedudukan sebagai perencana, pelaksana pengumpulan data, analisis, penafsir data dan pada akhirnya menjadi pelapor hasil penelitiannya ${ }^{34}$.

\section{Keabsahan Data}

Pemeriksaan keabsahan data menggunanakan teknik triangulasi yang merupakan sebuah teknik pemeriksaan keabsahan data dengan memanfaatkan sesuatu di luar data untuk keperluan pengecekan data. Adapun triangulasi yang digunakan adalah triangulasi metode dan sumber. Untuk memperoleh data dalam penelitian digunakan metode pengamatan, wawancara dan analisa dokumen yang diperoleh. Untuk kemudian dilakukan teknik triangulasi sumber yang dilakukan dengan meminta penjelasan lebih lanjut. Data-data yang diperoleh dengan menggunakan informan langsung serta dengan informan lain yang mendukung. Triangulasi kemudian digunakan untuk membandingkan informasi yang diberikan oleh informan pada saat yang berbeda.

\footnotetext{
${ }^{34}$ Lexy Moleong, op.cit, hlm. 168.
} 


\section{Teknik Analisis Data}

Analisis data merupakan proses penyederhanaan data yang diperoleh dalam penelitian ke dalam bentuk yang lebih mudah ditelaah dan diimplementasikan. Sesuai dengan pendekatan penelitian menggunakan analisis deskriptif maka analisis data yang digunakan menggunakan proses :
a. Reduksi data (data reduction)
b. Penyajian data (data display)
c. Penarikan kesimpulan dan verifikasi (conclusion drawing and verification)

\section{Hasil Penelitian}

1. Latar Belakang Keluarga dengan Pola Karir Ganda di Wilayah Mangir, Sendangsari, Pajangan, Bantul, Yogyakarta memilih Pola Karir Ganda

Pola karir ganda yang mengetengahkan keberadaan suami dan istri dalam keluarga dengan sama-sama memiliki pekerjaan tentunya berawal dari beberapa latar belakang keluarga menentukan pola tersebut. Keluarga yang memilih adanya pola karir ganda atau suami istri yang sama-sama bekerja tentunya memiliki beberapa alasan. Dari hasil penelitian terhadap keluarga dengan pola karir ganda di wilayah Mangir, Sendangsari, Pajangan, Bantul, Yogyakarta diketahui latar belakangnya adalah berawal dari suami istri yang sudah sama-sama bekerja. sebelum suami istri menikah semuanya telah memiliki pekerjaan. Pekerjaan yang ditekuni berbeda, artinya tidak dipertemukan dalam satu wilayah kerja namun justru karena sebab yang lain. Misalnya seperti organisasi dan perkenalan biasa. Prinsip yang mendasari masingmasing pihak untuk memperoleh pasangan yang sudah bekerja disebabkan ada beberapa faktor, yakni:

\section{a. Ketidaksengajaan}

Dalam hal ini yang dimaksud adalah dalam proses memperoleh pasangan yang tidak harus sudah memiliki pekerjaan. Namun ternyata memang diberikan pasangan yang sudah memiliki pekerjaan. Ada pemikiran bahwa ketidakharusan mendapatkan pasangan yang bekerja disebabkan karena misalnya suami telah memiliki pekerjaan. Ada pula yang mengatakan bahwa memang secara tidak sengaja ketika akan menikah istri mendapatkan pekerjaan. seperti yang diungkapkan oleh Bapak DA tentang latar belakang menikah dengan istri yang sudah bekerja:" Yo kur kebetulan hahaha... keetulan kan istri saya dulu waktu itu kan belum bekerja. tapi pas udah jadi istri ya udah bekerja" 35 .

b. Keinginan untuk mendapat pasangan yang bekerja/ prinsip

Keinginan atau prinsip personal untuk mendapatkan pasangan yang telah memiliki pekerjaan disebabkan karena beberapa hal seperti untuk memenuhi kebutuhan ekonomi dengan lebih baik seperti yang dikemukakan oleh Bapak AA:

\footnotetext{
${ }^{35}$ Wawancara dilakukan pada hari Minggu, 4 April 2010 pukul 10.00 WIB di rumah Bapak DA.
} 
| Problematika Keluarga dengan Pola Karir Ganda

"Memang prinsip saya sebelum menikah ingin memiliki istri yang sudah berpenghasilan. Entah penghasilan apapun itu agar kebutuhan ekonomi keluarga dapat terpenuhi dengan cukup. Sehingga ketika kemudian mencari calon pendamping menjadi kriteria saya memang untuk mencari calon yang sudah bekerja" 36 .

Selain itu alasan lain yang melatarbelakangi sesorang memiliki prinsip ingin berpasangan dengan pasangan yang sudah bekerja adalah karena alasan pekerjaan ideal wanita atau istri dan kontribusi karir dalam keluarga seperti yang diungkapkan oleh bapak BA:

"Dulu memang bercita-cita, istri kalau bisa kalau diridhoi Allah itu satu perawat, dua guru. Yo pilihan itu. Dan jatuhnya ke guru kebetulan. Ini yang saya syukuri juga. Kalau pertimbangan saya kalau guru itu minimal bisa membantu proses pendidikan secara dasar anak terutama waktu kecil. Karena saya merasa kalo pekerjaan saya itu sampai waktunya itu tidak terbatas, tidak bisa dipastikan selesainya kapan. Dan lagi posisinya jauh. Jarak jauh itu kan akan mempengaruhi tingkat berkumpul. La itu kan kalo samasama pegawai kantor misalnya kemudian pulangnya sama-sama sore kan kasihan anak. Tapi kalo ini ya saya pikir obsesi saya dulu kalo

\footnotetext{
${ }^{36}$ Wawancara dilakukan pada hari Minggu, 21 Maret 2010 pukul 10.00 WIBdi rumah AA
}

guru atau perawat kan sama-sama di rumah" 37 .

Terdapat pertimbangan yang lain yang merupakan sebuah pilihan seperti yang dikemukakan oleh bapak CA bahwa ketika dihadapkan dengan pilihan istri yang sudah bekerja atau belum bekerja, maka akan lebih memilih istri yang sudah memiliki pekerjaan meskipun secara prinsip tidak masalah memperoleh istri yang tidak memiliki pekerjaan.

Beberapa hal di atas ketika ditelaah maka selaras dengan teori Rasionalitas yang dikemukakan oleh Max Weber bahwa ada pertimbangan sadar dan pilihan bahwa tindakan tersebut dinyatakan inidvidu. Tindakan rasional instrumental salah satunya yang merupakan sebuah perspektif tindakan yang menyatakan bahwa pertimbangan dan pilihan yang dihadapkan pada seorang individu berhubungan dengan tujuan tindakan tersebut serta alat yang tersedia untuk mencapainya. Individu memiliki pertimbangan tujuan yang mungkin diinginkannya dan berdasar atas kriteria menentukan satu pilihan diantara beberapa tujuan itu pula. Kemudian individu akan memilih dan menyesuaikan alat untuk mencapai tujuan yang diinginkan tersebut. Pertimbangan rasional atas alternatif dilakukan oleh individu dengan meletakkan hubungan

\footnotetext{
${ }^{37}$ Wawancara dilakukan pada hari Kamis, 25 Maret 2010 pukul 20.00 WIB di rumah Bapak BA.
} 
tujuan dengan hasil yang mungkin dari pencapaiannya ${ }^{38}$. Sehingga dengan uraian di atas jelas bahwa ketika dihadapkan pada pilihan ingin memiliki pasangan yang telah bekerja dan belum bekerja, individu akan mengalami proses pertimbangan rasional terhadap tujuan yang dicapai. Seorang lakilaki atau perempuan memiliki keinginan untuk mendapatkan pasangan yang telah bekerja dengan beberapa pertimbangan rasional bahwa dengan pasangan yang bekerja maka kehidupan ekonomi keluarga akan terjamin, kehidupan anak akan terjamin, kekuatan hidup keluarga akan lebih baik dan sebagainya. Namun dengan pasangan yang belum bekerja maka kehidupan ekonomi belum mampu tercukupi, kebutuhan di masa mendatang akan semakin besar dan sebagainya. Sehingga menjadi satu pilihan rasional bagi laki-laki atau perempuan yang menginginkan untuk mendapatkan pasangan yang sudah bekerja. Selain itu seperti yang diungkapkan oleh bapak BA dalam alasannya menginginkan pasangan yang bekerja dengan bidang pekerjaan tertentu sebagai guru atau perawat dengan alasan jika guru maka akan menunjang pendidikan anak-anak serta jika perawat maka akan berkontribusi positif terhadap kesehatan keluarga, maka terlihat ada pertimbangan rasional lain selain keuntungan ekonomi yang ingin didapatkna oleh keluarga dengan pola karir

\footnotetext{
${ }^{38}$ Doyle Paul Johnson, Teori Sosiologi Klasik dan Modern Jilid I, Jakarta: Gramedia, 1988, hlm. 220.
}

ganda. Hal ini berarti bahwa bidang pekerjaan juga menjadi satu pertimbangan yang mempengaruhi pilihan rasional individu.

Secara struktural fungsional suatu sistem seperti yang dikemukakan oleh Talcott Parsons bahwasanya dalam sebuah sistem satu fungsi elemen akan mempengaruhi fungsi yang lain, maka disinilah pilihan rasional tersebut ditempatkan. ${ }^{39}$ Pertimbangan masa depan yang melihat pada penempatan fungsi peran suami istri dalam keluarga menjadi satu pertimbangan seorang laki-laki dalam menentukan pasangan hidupnya. Karir istri tidak hanya akan berfungsi dalam dunia kerjanya namun menjadi harapan suami bahwa hal itu turut memberikan fungsi positif dalam keluarga. Sehingga bukan hanya menginginkan pasangan yang sebatas memiliki pekerjaan dan penghasilan namun adalam dengan pertimbangan fungsional dan kontribusinya terhadap sistem keluarga.

2. Problematika yang Dialami Keluarga dengan Pola Karir Ganda di Wilayah Mangir, Sendangsari, Pajangan, Bantul, Yogyakarta

Keluarga dengan pola karir ganda tidak hanya terjadi pada keluarga di perkotaan namun beberapa keluarga di perdesaan yang notabene masih erat dengan sifat tradisional juga sudah mengalami perubahan. Sudah tidak asing lagi adanya komposisi

${ }^{39}$ K.J Veeger, Realitas Sosial, Jakarta: Gramedia, 1986, hlm. 201-202. 
keluarga terdiri atas suami istri yang sama-sama bekerja. Seperti yang terjadi pada masyarakat di Wilayah Mangir, Sendangsari, Pajangan, Bantul, Yogyakarta bahwasanya masyarakat dengan karaktersitik perdesaan yang masih melekat terdapat beberapa keluarga yang di dalamnya merupakan keluarga dengan pola karir ganda. Bidang-bidang pekerjaan yang terklasifikasi dalam hal ini tentunya adalah bidang pekerjaan yang ada di lingkungan masyarakat tersebut.

Beberapa keluarga yang di dalamnya terdapat pola karir ganda terdiri atas pekerjaan sebagai PNS, Polisi, dan swasta. Keluarga dengan pola karir ganda tentunya memiliki beberapa keuntungan yang didapatkan. Namun hal tersebut tentunya juga tidak lepas dari beberapa problematika yang dihadapi. Dari beberapa subjek yang diwawancara dan telah diperoleh deskripsi terhadap karakter serta kondisi rumah tangga masing-masing keluarga ternyata memang kehidupan keluarga dengan pola karir ganda tidak lepas dari berbagai problematika yang dihadapi. Problematika yang dihadapi tentunya dalam kapasitas keluarga kelas menengah di masyarakat perdesaan dan secara nyata dialami serta dirasakan oleh masyarakat dalam setiap keluarga dengan pola karir ganda. Problematika yang dihadapi oleh keluarga dengan pola karir ganda di Wilayah Mangir, Sendangsari, Pajangan, Bantul, Yogyakarta diantaranya: a. Tidak dapat berpartisipasi dalam kegiatan sosial kemasyarakatan

Manusia sebagai makhluk individu dan makhluk sosial tentunya hidup di tengah-tengah masyarakat yang memiliki konsensus. Adanya lembaga sosial, organisasi sosial serta perkumpulan-perkumpulan sebagai suatu aktivitas dan struktur sosial dalam masyarakat memiliki sebuah kekuatan atau norma tertentu yang secara tidak langsung mengikat individu yang ada di dalamnya. Keluarga adalah elemen penting dalam sebuah masyarakat. Partisipasi individu dalam keluarga menjadi bagian penting terwujudnya masyarakat yang kondusif. Organisasi, lembaga, serta perkumpulan sosial di masyarakat juga sebagai sebuah kontrol dalam kelangsungan hidup di masyarakat. Sehingga disadari bahwa keberadaannya berasal dari anggota masyarakat itu sendiri.

Keluarga dengan pola karir ganda menitikberatkan pada suami istri dalam keluarga tersebut yang sama-sama bekerja. suami istri yang sama-sama bekerja memiliki waktu dalam batas masing-masing sesuai dengan bidang pekerjaan mereka. Sehingga tanggung jawab tersebut yang harus dipatuhi oleh setiap suami dan istri dalam keluarga yang memiliki pekerjaan. Hal inilah yang teryata cukup menimbulkan kesulitan tertentu dalam keluarga dengan pola karir ganda di Wilayah Mangir, Sendangsari, Pajangan, Bantul, Yogyakarta. Karena 
padatnya waktu bekerja maka tidak dapat berpartisipasi dalam aktivitas sosial di masyarakat. Hal ini tentu menjadi satu hal tersendiri yang harus dikorbankan, karena mengingat bahwa keberadaan individu dalam keluarga tidak terlepas dari masyarakat. Kesulitan tersebut dialami individu tentunya dengan pertimbangan rasional karena kesehatan, keluarga dan sebagainya. Sehingga tidak dapat berpartisipasi dalam aktivitas sosial di masyarakat yang secara sadar sebenarnya sangat diperlukan. Sehingga kompensasi yang dilakukan adalah dengan memberikan sumbangan sosial dan iuran sosial sebagai upaya untuk tidak menimbulkan sanksi-sanksi sosial yang lain di masyarakat.

\section{b. Keterbatasan kemampuan orang tua untuk mendampingi perkembangan proses belajar anak}

Perhatian yang diberikan orang tua tentunya berbeda-beda sesuai dengan karakteristik dan cara masing-masing orang tua sekaligus anak. Secara garis besar wujud atau bentuk perhatian tersebut dapat berupa kontrol prestasi sekolah anak, pendampingan belajar, motivasi kegiatan belajar anak, dan sebagainya. Dalam sebuah keluarga memiliki fungsi sosialisasi yang membutuhkan peran orang tua untuk mempelajari pola, tingkah laku, masyarakat, serta berbagai hal. Sehingga ketika anak memiliki aktivitas di sekolah maka setiap kembali ke rumah fungsi kontrol orang tua dalam proses sosialisasi anak sangat diperlukan.

Keluarga dengan pola karir ganda memiliki konsekuensi logis waktu orang tua yang terbagi-bagi untuk pekerjaan dan keluarga. dengan konsekuensi tersebut menjadi satu harapan memang keberadaan orang tua tidak meninggalkan fungsi kontrolnya untuk anak. Namun hal tersebut yang masih menjadi kesulitan dalam keluarga dengan pola karir ganda di Wilayah Mangir. Orang tua menyatakan bahwa ada kalanya kurang perhatian terhadap anak atau merasakan kurang maksimal perhatian yang diberikan kepada anak sehingga merasakan bahwa prestasi anak di sekolah tidak dapat maksimal bahkan anak mengalami hambatan dalam proses belajar. Seperti yang diungkapkan oleh ibu BB dalam wawancara:

"Kalo yang saya rasakan nek tak bandingke dengan teman-teman yang mungkin ibunya bisa full memantau anak-anaknya itu ya mbak, misalnya bisa ngasih perhatian kaya orang-orang yang 'kopen', bisa antar jemput sekolah, anaknya dileske itu kayaknya yo hasilnya lebih maksimal. La Dinda ki malah udah hampir 2 bulan mandeg sekolah juga e mbak katanya males. La aku yo raiso piepie $^{\prime 40}$.

Permasalahan selanjutnya adalah ketika anak di usia balita yang membutuhkan perhatian

\footnotetext{
${ }^{40}$ Wawancara dilakukan pada hari Selasa, 23 Maret 2010 pukul 18.30 WIB di rumah Bapak BA.
} 
| Problematika Keluarga dengan Pola Karir Ganda

orang tua justru dibiarkan untuk berada pada lingkungan bermain saja dalam proses belajarnya. Seperti yang dilakukan oleh salah seorang narasumber pada keluarga dengan pola karir ganda di Wilayah Mangir bahwa ia atau ibu tersebut jarang mendampingi anak belajar dan justru membiarkan anak belajar bersama teman-temannya. Hal ini akan berbahaya jika tidak dengan kontrol orang tua. Seperti yang diungkapkan oleh Falasifah Ani Yuniarti SKep Ns MAN Koordinator Program Studi Ilmu Keperawatan Fakultas Kedokteran UMY bahwa perkembangan seorang anak di usia toddler (1-3) tahun harus lebih diperhatikan. Karena pembentukan karakter anak dimulai pada fase ini. Perkembangan psikososial anak dipengaruhi oleh faktor empati, pola pengasuhan, kematangan dan kedewasaan ibu $^{41}$. Sehingga pernyataan salah satu narasumber dalam keluarga dengan pola karir ganda sebenarnya akan menimbulkan satu permasalahan jika tidak diperhatikan.

Kemudian memasuki era perkembangan teknologi yang semakin canggih, ketika anak tidak didampingi orang tua dengan benar, maka akan terdapat peluangpeluang anak untuk melakukan aktivitas menyimpang. Hal ini tentunya cukup berbahaya. Seperti

41 Indria Laksmi Gamayanti, “Anak Mulai Belajar Perkembangan Diri, Usia 1-3 Tahun Harus Lebih Diperhatikan", Terdapat pada Harian Kedaulatan Rakyat, Edisi Minggu Pon 10 Januari 2010. yang diungkapkan oleh Dr. Indria Laksmi Gamayanti seorang Psikolog Klinis Anak RSUP Dr Sardjito dalam artikelnya berjudul "Facebook Bisa Hambat Potensi Dasar Anak" yang mengatakan bahwa kemajuan teknologi sebenarnya dapat menghambat pengembangan potensi dasar anak karena mengalami keterbatasan kemampuan sosial di dunia nyata. Oleh sebab itu menghadapi kemajuan teknologi salah satunya facebook orang tua harus mengontrol dan memberikan pemahaman mengenai waktu anakanak dapat menggunakan dan memanfaatkan perkembangan teknologi tersebut sehingga aktivitas belajar dan perkembangan sosial anak tidak terganggu ${ }^{42}$. Secara nyata dalam aktivitas belajar memang anak sering menggunakan kemajuan teknologi tidak pada tempatnya. Seperti contoh yang diungkapkan oleh BC anak dari Bapak BA ketika diberikan pertanyaan mengenai orang tua dalam pendampingan belajar : "Emm. Ga juga sih. Yo cuma nemenin aja nungguin belajar atau ngga. Ntar tinggal sms an atau facebookan, he. Ya cuma dikasih tau aja suruh belajar yang bener ya"43. Artinya dalam hal ini menjadi suatu permasalahan ketika memang

42 Indria Laksmi Gamayanti, "Facebook Bisa Hambat Potensi Dasar Anak”, Terdapat pada Harian Kedaulatan Rakyat, Edisi Minggu Wage, 31 Januari 2010.

43 Wawancara dilakukan pada hari Kamis, 25 Maret 2010 pukul 19.00 WIB di rumah Bapak BA 
kurangnya pendampingan orang tua dalam proses aktivitas anak terutama belajar akan menimbulkan beberapa dampak yang buruk. Anak akan berbohong, anak belajar semaunya sendiri dan sebagainya.

$$
\text { Selain itu dalam }
$$

perkembangan teknologi yang semakin pesat juga menyebabkan orang tua menjadi terbatas kemampuannya untuk dapat mengikuti perkembangan pengetahuan anak di bidang tersebut. Orang tua yang memiliki pekerjaan dalam waktu tertentu kemudian ketika harus memperhatikan anak sampai pada masalah detail perkembangan teknologi ternyata juga mengalami sebuah kesulitan. Karena terus terang diakui oleh salah satu narasumber bahwa teknologi dan pengaruhnya dalam pendidikan terhadap anak telah membuat orang tua ketinggalan. Sehingga kemampuan mendampingi anak dalam proses belajar menjadi terbatas. Seperti contoh dikemukakan oleh salah satu narasumber:

“....Apalagi perkembangan ilmu pengetahuan sekarang itu sangat ketinggalan. Kalau selama SMP waktu saya dan SMP sekarang sudah beda apalagi Slamet di RSBI. Kalau Yuli dulu yo nggak anu, saya tidak bisa mendampingi. Jadi paling yo hanya menyanyakan, tanggung jawab kita. Yo setengah dibebaskan soale wis rangerti perkembangane mbak. Jan nek sekarang itu teknologi ya sudah canggih jadi anak-anak belajar sendiri, saya kadang sulit sekali mengikuti karena tidak sempat" 44 .

\section{c. Pengeluaran tidak terduga terkait dengan sumbangan untuk kegiatan hajatan rekan di masyarakat dan di kantor}

Hajatan atau dalam Bahasa Jawa sering disebut ewuh memang masih marak dilakukan pada masyarakat terutama di perdesaan. Hajatan berasal dari kata hajat yang berarti niat, maksud, keperluan, kebutuhan, pesta atau kenduri merupakan salah satu acara yang dilakukan biasanya untuk mengucap rasa syukur atas berkah yang diberikan ${ }^{45}$. Bentuk dari hajatan itu bermacam-macam sesuai dengan tradisi masyarakat sekitar. Ragam atau jenis acara yang sekiranya perlu diberikan hajatan pun berbeda-beda antara satu daerah dengan daerah lain.

Masyarakat Mangir yang notabene merupakan masyarakat perdesaan masih banyak melakukan berbagai acara hajatan dalam tradisinya. Hal inilah yang ternyata juga menimbulkan permasalahan bagi masyarakat di dalamnya. Kebiasaan memberikan sumbangan berwujud uang atau barang ketika tetangga hajatan pada waktu tertentu ternyata menimbulkan biaya tak terduga yang kadang tidak sedikit. Seperti itu pula yang dirasakan oleh beberapa keluarga

\footnotetext{
44 Wawancara dilakukan pada hari Minggu, 4 April 2010 pukul 11.00 WIB di rumah Bapak DA

45 J.S Badudu dan Sutan Muhammad Zain, Kamus Umum Bahasa Indonesia, Jakarta: Pustaka Sinar Harapan, 1996, hlm.483.
} 
Problematika Keluarga dengan Pola Karir Ganda

dengan pola karir ganda yang memiliki lingkungan masyarakat atau rekan di rumah dan di kantor baik kantor ayah maupun ibu. Sehingga dikatakan bahwa alokasi keuangan untuk kegiatan-kegiatan seperti itu justru sangat besar apalagi ketika rekan di kantor ada yang berhajat dan di lingkungan masyarakat rumah juga ada. Seperti yang diungkapkan oleh narasumber:

"Nggak mbak. Lha yo dari segi ekonomi juga ntar ngga mencukupi. Meskipun wes samasama kerja bapak ibu tapi yo tetep belum bisa mencukupi sepenuhnya. Apalagi kalo buat sosial kayak nyumbang-nyumbang kui lho mbak. Kadang-kadang rak gak menentu to. La malah iso luwih okeh e mbak. Misalnya nek pas musim kae, kancane bapak neng kantor, engko urung kancaku, e lha neng kene ya ada dan kadangkadang ngga cuma satu dua, kene mantu kono nyewu rung sik engko ngobong boto" 46 .

\section{d. Tidak dapat diselesaikannya pekerjaan rumah tangga dengan baik}

Ketegangan atau stress

karena pembagian tugas rumah tangga memang menjadi salah satu kerawanan dalam keluarga yang sama-sama bekerja ${ }^{47}$. Dalam

\footnotetext{
46 Wawancara dilakukan pada hari Selasa, 23 Maret 2010 pukul 18.30 WIB di rumah Bapak BA.

${ }^{47}$ G. Rowatt, dkk, Bila Suami Istri Bekerja: The Two Career Marriage, Yogyakarta: Kanisius, 1990, hlm. 16.
}

keluarga yang sama-sama bekerja setiap sampai di rumah pasti telah menanti tugas-tugas rumah tangga yang belum diselesaikan. Apalagi dalam hal ini ketika dalam keluarga tidak memiliki pembantu rumah tangga. Sehingga kadang memang muncul sistem kerjasama yang dilakukan oleh suami istri. Ketika suami mau mengerjakan pekerjaan yang notabene merupakan pekerjaan yang dianggap pekerjaan wanita seperti memasak, mencuci dan sebagainya tentu tidak akan menjadi suatu masalah yang membertakan namun ketika suami enggan melakukan hal demikian maka akan cukup menjadi beban terutama bagi istri atau wanita. Bantuan dan kesediaan anak sangat dibutuhkan dalam hal seperti ini.

Pada keluarga dengan pola karir ganda di Mangir, permasalahan seperti di atas ternyata juga terjadi. Kesulitan orang tua untuk dapat menyelesaikan pekerjaan rumah tangga meskipun sudah dilakukan kerjasama masih tetap terjadi. Hal ini dikarenakan pekerjaan di kantor atau tempat bekerja yang cukup padat seperti yang diungkapkan oleh narasumber:

"Kalo pekerjaan rumah itu sesampainya mbak. La gimana lagi, jadinya kalo ya maunya ya dibagibagi tapi kan watunya yang ga mungkin to mbak jadi ya trus ya gitu ya se kira-kira kalo ada waktu ya dikerjain ya kalo ga ya udah besok-besok kalo ada waktu. Jadi tidak harus gitu, he ya pinginnya itu rutin tapi kadang-kadang waktu 
kadang yang capek, nha itu yang e daripada kecapean ya anu berhenti dulu gitu" 48 .

\section{e. Aturan waktu bekerja setiap saat/ tidak menentu yang harus mengorbankan kebersamaan bersama keluarga \\ Lingkungan kerja juga} merupakan sebuah masyarakat yang memiliki aturan-aturan untuk anggota di dalamnya. Aturan serta pekerjaan yang dilakukan tentunya sesuai dengan bidang pekerjaan yang ada. Untuk aktivitas pekerjaan tertentu kadang membutuhkan waktu yang tidak menentu. Sehingga kebersamaan bersama keluarga juga menjadi satu hal yang memang harus dikorbankan. Seperti ungkapan salah satu narasumber yang bekerja sebagai polisi yang menyatakan bahwa aktivitas pekerjaannya kadang kala tidak menentu. Meskipun libur namun ketika ada perintah mendadak untuk segera ke kantor maka mau tidak mau dan harus siap untuk langsung berangkat. Hal ini menimbulkan satu kesulitan tertentu yang dihadapi oleh salah satu keluarga dengan pola karir ganda di Mangir. Selain itu aktivitas pekerjaan yang padat yang menuntut hingga larut malam dan dirasakan oleh keluarga dengan pola karir ganda di wilayah tersebut juga menimbulkan kesulitan dan permasalahan tersendiri. Umunya prinsip mengutamakan pekerjaan

\footnotetext{
48 Wawancara dilakukan pada hari Minggu, 21 Maret 2010 pukul 10.30 WIB di rumah Bapak AA
}

kemudian menimbulkan kesulitan dan hambatan untuk dapat berkumpul bersama keluarga.

\section{f. Kesalahan komunikasi untuk "hubungan" suami istri \\ Permasalahan selanjutnya} yang dialami oleh keluarga dengan pola karir ganda di Mangir adalah mengenai hubungan suami istri. Dari sumber yang didapat diperoleh keterangan bahwa komunikasi yang terjadi sering mengalami hambatan. Ketika kedua belah pihak selesai dari pekerjaan di kantor maka kadang terjadi salah komunikasi di rumah yang menyebabkan goyahnya hubungan suami istri. Maka yang terjadi kemudian hanya saling diam dan membiarkan. Seperti yang diungkapkan oleh narasumber:

"Kalau ada masalah ya saya tinggal tidur aja..hehehe. ada masalah sama suami, mungkin kurang komunikasi ketika satu keinginan misalnya suami istri kan kadang kebutuhan suami istri tidak ditanggapi oleh yang lain ya udah ditinggal tidur aja. Hehhe. Ya kebutuhan suami istri tanda kutip itu lho dek, hehehe. Kadang memang kami komunikasi masih sering kurang. Kalau saya capek bekerja langsung istirahat atau sebaliknya tapi ternyata salah satu sebenarnya mengenai wajar hubungan suami istri misalnya, tapi tidak ditanggapi. Itu ya nanti terus diem-dieman aja. Tapi terus ditinggal tidur, heee...." 49 .

\footnotetext{
49 Wawancara dilakukan pada hari Minggu, 11 April 2010 pukul 16.00 WIB di rumah Bapak CA
} 
Problematika Keluarga dengan Pola Karir Ganda

Hal ini menjadi satu kenyataan yang dialami oleh sebuah keluarga dengan pola karir ganda di Mangir. Dalam teori evolusi keluarga modern juga disebutkan bahwa aktivitas utama dalam keluarga memiliki 3 fungsi pokok yakni prokreasi dan pemeliharaan anak, kebutuhan seks, dan provision of home (kenyamanan rumah tangga $)^{50}$. Dalam fungsi tersebut memang keluarga modern yang memiliki aktivitas tidak hanya dalam lingkup domestik akan mengalami perkembangan fungsi terhadap kebutuhan utama dalam sebuah keluarga. Sehingga ketika terjadi problem dalam menghadapi salah satu permasalahan seperti kebutuhan seks memang menjadi satu akibat yang terjadi karena perkembangan fungsi keluarga yang disebabkan karena kesibukan atau tugas seorang ayah atau ibu sehingga meninggalkan fungsi yang lain.

g. Krisis percaya diri terhadap peran seorang $i b u$, istri dan seorang pekerja

Memasuki dunia baru atau lingkungan yang sebelumnya belum pernah dirasakan menjadi satu kesulitan tersendiri bagi individu. Seperti yang diungkapkan oleh kaum ibu pada keluarga dengan pola karir ganda di Mangir. Menjadi seorang istri, ibu, dan seorang pekerja ternyata akan menimbulkan rasa tersendiri yakni krisis percaya

\footnotetext{
${ }^{50}$ Khairuddin, Sosiologi Keluarga, Yogyakarta: Nur Cahaya, 1985, hlm. 67-70.
}

diri. Beban pekerjaan di kantor, beban pekerjaan rumah tangga dan tanggung jawab sebagai ibu membayangi pikiran dengan rasa percaya diri yang terkadang pesimis mampu atau tidak untuk dapat melaksanakan tugas-tugas tersebut. Hal ini terutama dirasakan oleh ibuibu muda atau dalam tahap perkawinan yang masih muda.

Proses sosialisasi menjadi sangat penting dalam hal ini. Sosialisasi merupakan proses individu untuk mempelajari nilai, norma dalam masyarakat sehingga individu mampu untuk melaksanakannya. Dalam melaksanakan sosialisasi tersebut tidak jarang individu mengalami hambatan. Maka disinilah ketika seorang ibu mengalami krisis percaya diri sebenarnya ia merasakan hambatan terhadap sosialisasi. Sehingga dukungan dan motivasi baik dari suami, anak serta lingkungan sangat dibutuhkan.

\section{h. Terbenturnya agenda pekerjaan di tempat kerja dengan kegiatan yang lain Individu adalah makhluk} yang bebas bergerak. Individu memiliki kesempatan untuk dapat menjadi bagian dari masyarakat yang satu dan masyarakat yang lain. Dalam hal ini mengandung konsekuensi bahwa individu juga harus melaksanakan aturan pada masyarakat tertentu yang mengikatnya. Dalam lingkungan pekerjaan individu terikat dalam aturan pekerjaan, dalam lingkungan masyarakat individu terikat pada aturan atau norma yang berlaku di 
dalamnya, dan pada lingkungan keluarga individu juga menmiliki aturan yang mengikatnya. Semua itu menurut Durkheim disebut sebagai fakta sosial yang mengikat individu, berlaku umum, dan bersifat memaksa ${ }^{51}$.

Menjadi sebuah problematika tersendiri yang dialami oleh keluarga dengan pola karir ganda di Mangir adalah ketika menghadapi aturan-aturan atau agenda pekerjaan di kantor yang berbenturan dengan kegiatan di masyarakat atau di lingkungan sekolah anaknya yang juga membutuhkan kehadiran orang tua. Dalam menghadapi hal seperti ini suami istri di keluarga dengan pola karir ganda merasakan kesulitan untuk mengatasinya karena pekerjaan dan kegiatan yang lain sama-sama penting. Sehingga kadang-kadang ada salah satu yang dikorbankan. Ketika berhadapan dengan lingkungan sekolah anak dan dengan terpaksa orang tua tidak dapat memenuhi agenda sekolah dikarenakan sibuknya pekerjaan maka anak akan memiliki sikap yang bermacam-macam. Salah satunya seperti yang diungkapkan oleh narasumber:

"Mungkin eee..agak kurang pada, misal kita mau ada acara apa gitu tapi tabrakan sama pekerjaan orang tua, jadi ngga bisa misalkan kita mau ada acara di sekolah yang sama orang tua itu ngga ada yang nemenin gitu, ya udah mau

${ }^{51}$ Doyle Paul Johnson, op.cit, hlm.177. bagaimana lagi. Itu mungkin kaya gitu" 52 .

Selain agenda sekolah seperti di atas, agenda masyarakat yang lain kadang menjadi satu kesulitan tertentu yang dihadapi oleh suami istri yang sama-sama bekerja. karena kehidupan masyarakat Mangir masih sangat erat, maka ketika ada kegiatan seperti hajatan dan sebagainya pasti mengundang keluarga dan kerabat serta tetangga. Dalam menghadapi hal seperti ini bagi keluarga dengan pola karir ganda sering mengalami kesulitan tersendiri untuk mengatur waktu. Seperti yang diungkapkan oleh narasumber:

“....Ya saya mengutamakan pekerjaan mbak, karena apa saya punya penghasilan ya dari kantor. Jadi saya walaupun repotnya seperti apa itu kalau bisa dikomunikasikan ya dikomunikasikan. Misalnya saya harus masuk tapi ada manten atau simbah yang meninggal nah itu bisa dikomunikasikan lewat telepon. Tetapi misalnya saya pas saat seperti itu rumah ribet sekali tetapi harus memanggil orang tua siswa itu yang kadang-kadang berbenturan" 53 .

\footnotetext{
52 Wawancara dilakukan pada hari Kamis, 25 Maret 2010 pukul 19.00 WIB di rumah Bapak BA

${ }^{53}$ Wawancara dilakukan pada hari Minggu, 4 April 2010 pukul 11.00 WIB di rumah Bapak DA
} 
Problematika Keluarga dengan Pola Karir Ganda

\section{i. Pendampingan khusus untuk anak yang menyebabkan pekerjaan tidak maksimal}

Hal ini dirasakan oleh salah satu narasumber yang memiliki anak berkebutuhan khusus. Menggarisbawahi permasalahan yang diungkapkan dalam hal ini adalah masalah terkait dengan keluarga dan pekerjaan yang dialami oleh keluarga dengan suami istri yang sama-sama bekerja, maka salah satu kesulitan atau permasalahan yang dihadapi adalah sebuah keluarga yang memiliki anak berkebutuhan khusus (ABK) adalah ketika harus memperhatikan anak secara khusus maka menimbulkan tidak maksimalnya pekerjaan yang dikerjakan di kantor serta sulitnya manajemen waktu. Masalah yang dialami orang tua adalah ketika harus menyanding anak setiap saat sehingga dari sana terkadang membuat rutinitas kerja ibu tidak disiplin, pekerjaan kantor menjadi menumpuk dan sebagainya. Selain itu aktivitas sosial di masyarakat juga kesulitan karena ketika ada waktu luang dipergunakan untuk anak tersebut. Seperti yang diungkapkan oleh narasumber:

"Neng nek berorganisai sing sue, yo karena punya anak sing berkebutuhan khusus yo ora iso. Kecuali nek malam hari. Ora iso maksimal. Neng nek tilik wong loro, layat kui diselakke" 54 .

\footnotetext{
54 Wawancara dilakukan pada hari Minggu, 4 April 2010 pukul 10.00 WIB di rumah Bapak DA
}

j. Lelah atau stress terhadap
padatnya pekerjaan
Setiap pasangan karir ganda pasti menghadapi beban pekerjaan yang cukup berat. Padatnya pekerjaan di kantor dengan segala macam aktivitas pekerjaan akan menimbulkan stress dan lelah tersendiri oleh suami maupun istri.

Hal inilah yang dirasakan oleh keluarga dengan pola karir ganda di Mangir baik keluarga yang masih muda, pertengahan maupun yang sudah lama berumah tangga. Kelelahan menghadapi pekerjaan kantor menjadi satu kesulitan dan permasalahan tersendiri. Aktivitas kerja yang padat menimbulkan stress. Seperti yang diungkapkan oleh narasumber: " ....Capek ya. Terutama capek pikiran nanti ketika dihadapkan pada pekerjaan yang banyak. Jadi nggak sempat apa-apa untuk keluarga" 55 .

Ketika rasa lelah dan stress tersebut mencapai puncak kadang memang menimbulkan pikiran individu untuk menemukan satu titik tertentu misalnya berhenti bekerja dan sebagainya seperti yang diungkapkan narasumber: “....Kadang-kadang gandeng le nyambut gawe saking kesele yo mbak. Kadang-kadang koyo arep njukuk pensiun dini" 56 .

Hal-hal seperti inilah yang menjadi pilihan dalam sebuah

\footnotetext{
${ }^{55}$ Wawancara dilakukan pada hari Minggu, 18 April 2010 pukul 15.30 WIB di rumah Bapak EA

56 Wawancara dilakukan pada hari Minggu, 4 April 2010 pukul 10.00 WIB di rumah Bapak DA
} 
keluarga yang sudah berkomitmen untuk memilih pola karir ganda atau suami istri yang sama-sama bekerja. Rasa lelah dan stress menjadi satu konsekuensi yang harus diambil. Seperti yang diungkapkan oleh Parker dalam bukunya yang menyatakan bahwa ada suatu beban berlebihan (over load) yang akan dialami oleh pasangan yang sama-sama bekerja karena semakin banyaknya tanggung jawab. Kelelahan atau stress adalah konsekuensi yang dialami pasangan-pasangan tersebut.

k. Kurangnya kontrol orang tua yang menimbulkan permasalahan pada anak

Kontrol orang tua diperlukan dalam mengontrol perkembangan anak dan keluarga. selain itu berfungsi sebagai sistem pengawasan kolaborasi orang tua sangat diperlukan agar anak melakukan pergaulan yang tidak melampaui batas. Sehingga dari itulah orang tua menerapkan polapola didik yang berbeda sesuai dengan karakter anak.

Orang tua yang sama-sama bekerja atau dalam keluarga dengan pola karir ganda memiliki waktu yang terbatas pada pengawasan anak. Karena ketika orang tua samasama bekerja tentunya anak akan berada di rumah atau berada pada lingkungan tanpa pengawasan orang tua. Maka fungsi sosialisasi keluarga yang memberikan pembentukan kepribadian terhadap anak untuk berinteraksi mempelajari pola, tingkah laku, sikap, keyakinan, cinta, cita, dan nilai-nilai dalam masyarakat akan sangat dirasakan manfaatnya. Anak menjadi pribadi yang berkembang, mempelajari apapun yang ia temui.

Menjadi suatu permasalahan apabila terjadi pada salah satu kasus yang dialami oleh salah satu keluarga dengan pola karir ganda di Mangir, ketika anak menyatakan bahwa keberadaan orang tua di tempat kerja menjadi kesempatan besar bagi anak untuk dapat bermain sepuasnya di rumah bersama teman-teman. Seperti ungkap seorang narasumber ketika diberi pertanyaan terhadap rasa keberatannya ketika orang tua bekerja:

"Engga. Kan temen-temen pada maen, kalo ada ibuk sering isin e malu. Gitu, kalo ga ada bebas. Ya maennya sering di sini di luar sama di dalem. Pokoknya malah bebas lah, temenku siapa aja ke sini. Kalo ada orang tua kan nggak bisa" 57 .

3. Cara Menangani Problematika yang Dialami Keluarga dengan Pola Karir Ganda di Wilayah Mangir, Sendangsari, Pajangan, Bantul, Yogyakarta

Keluarga dengan pola karir ganda di Wilayah Mangir, Sendangsari, Pajangan, Bantul memiliki berbagai macam problematika terkait dengan kesulitan atau permasalahan kehidupan keluarga tersebut. Hal tersebut sekali lagi tidak lepas dari

57 Wawancara dilakukan pada hari Minggu, 21 Maret 2010 pukul 11.00 WIB di rumah Bapak AA. 
Problematika Keluarga dengan Pola Karir Ganda

berbagai keuntungan yang diperoleh dengan pola karir ganda. Beberapa problematika di atas menjadi permasalahan yang bersifat sehari-hari atau masalah biasa dan umum serta masalah-masalah khusus yang dialami oleh keluarga. Problematika tersebut dapat diatasi dengan beberapa cara oleh masingmasing keluarga. Proses penyelesaian dari permasalahan dan kesulitan yang dihadapi oleh keluarga dengan pola karir ganda bermacam-macam diantaranya:

\section{a. Komunikasi}

Cara ini digunakan dalam mengatasi permasalahan ketika orang tua memiliki keterbatasn waktu atau frekuensi kurang untuk bersama anak dan keluarga karena aktivitas pekerjaan. seperti yang diungkapkan oleh narasumber bahwa ketika siang hari sering menelpon anak untuk menanyakan aktivitas dan sebagainya. Karena ketika nanti sampai di rumah sudah larut malam dan anak sudah tidur.

Selain itu komunikasi juga digunakan untuk menjembatani kesulitan ketika menghadapi aktivitas atau pekerjaan kantor dan kegiatan di masyarakat yang samasama penting. Misalnya ada jadwal pekerjaan di kantor namun tiba-tiba di lingkungan masyarakat ada tetangga yang meninggal dan sebagainya.

\section{b. Peran pihak ketiga}

Pihak ketiga atau dapat didefinisikan dalam pembantu, pengasuh anak baik yang ikut tinggal bersama keluarga maupun di luar keluarga diperlukan oleh beberapa keluarga yang memang tidak dapat mengatasi permasalahan terkait karena kesibukan anggota keluarga. Pihak ketiga tersebut bertugas sesuai dengan tugas yang diberikan. Pihak ketiga menjadi salah satu alternatif yang membantu memecahkan kesulitan dan permasalahan keluarga dengan pola karir ganda.

Pada keluarga dengan pola karir ganda di Wilayah Mangir pihak ketiga terdefinisikan dalam berbagai macam hal. Pembantu yang tinggal di rumah serta pengasuh anak yang tidak ikut tinggal bersama keluarga atau hanya sebagai pengasuh anak. Hal ini menjadi cara menyelesaikan kesulitan yang dialami anggota keluarga karena ditinggal oleh orang tua yang sama-sama bekerja.

c. Membagi tugas pekerjaan rumah tangga

Untuk keluarga yang pada umumnya sudah memiliki anak yang cukup dewasa atau remaja sehingga tidak memerlukan pengasuh anak atau pihak ketiga dan juga pembantu rumah tangga untuk mengerjakan pekerjaan rumah tangga, akan memecahkan kesulitan-kesulitan dalam tugas rumah tangga dengan membagi tugas tersebut antara suami dan istri. Hal ini menjadi cara penyelesaian agar tugas rumah tangga dapat tersentuh. Ada kerjasama dalam hal ini dan pada umumnya diatur oleh ibu. Pada keluarga dengan pola karir ganda di Wilayah Mangir tugas-tugas rumah tangga dilakukan secara kolaborasi 
ayah dan ibu dengan tidak meninggikan prinsip bahwa pekerjaan atau tugas rumah tangga merupakan tugas wanita saja. Meskipun suami atau laki-laki sebatas mengerjakan pekerjaan yang dibutuhkan atau diminta oleh istri namun terlihat kerjasama dalam tugas rumah tangga.

\section{d. Didiamkan}

Pada permasalahan tertentu dalam hal ini menyangkut kepentingan suami istri ada cara penyelesaian dengan didiamkan. Karena secara etis tidak tepat ketika memberikan pemaksaan kepada salah satu pihak. Seperti yang diungkapkan oleh narasumber bahwa ketika mengahadapi suatu permasalahan mis komunikasi dalam "hubungan" suami istri maka cara penyelesaiannya adalah didiamkan dan ditinggal tidur.

\section{e. Salah satu mengalah}

Suatu konflik rumah tangga atau cekcok yang dialami oleh keluarga tertentu merupakan permasalahan yang sering terjadi. Permasalahannya dalam hal ini yang diketengahkan adalah ketika dalam keluarga dengan pola karir ganda mengalami permasalahan yang disebabkan karena pekerjaan masing-masing sehingga menimbulkan konflik atau cekcok. Cekcok itu sendiri dapat terjadi karena rasa lelah, perselisihan nilai tertentu dan sebagainya. Konflik yang terjadi dalam keluarga dengan pola karir ganda di Wilayah Mangir masih dalam taraf konflik kecil yang belum menimbulkan akibat desdruktif yang cukup berbahaya. Justru konflik memperbaiki hal-hal yang perlu dibenahi dalam keluarga tersebut. Seperti yang diungkapkan oleh Weber bahwa sebuah konflik dapat berkontribusi positif membangun persatuan dalam sistem. Dalam sistem keluarga juga demikian, konflik yang terjadi dengan penanganan yang baik akan dapat memperkuat sistem keluarga tersebut. Dalam kondisi demikian pada keluarga dengan pola karir ganda di Mangir permasalahan konflik tersebut diselesaikan dengan cara salah satu pihak mengalah untuk dapat meredamkan konflik. Seperti halnya cara penanganan konflik salah satunya adalah ada pihak-pihak yang mengalah untuk dapat meredamkan konflik tersbeut.

\section{f. Meminta saran}

Cara ini dilakukan oleh istri atau ibu dalam keluarga dengan pola karir ganda yang mengalami krisis percaya diri terhadap peranperannya. Istri atau ibu yang mengalami krisis kepercayaan diri tersebut cenderung mengalamai ketakutan akan keberhasilan peran yang ada dalam dirinya. Selain sebagai istri dan $i b u$, seorang wanita dalam keluarga dengan pola karir ganda juga bekerja sehingga ada peran publik yang ia sandang. Tugas dan tanggung jawab yang beraneka ragam membuat seorang wanita kadang mengalami krisis menghadapi perannya tersebut. sehingga yang dikatakan oleh narasumber bahwa salah satu mengatasi keadaan demikian adalah dengan berbagi cerita atau meminta saran kepada suami untuk peranperan yang ia kerjakan. Melalui cara tersebut akan diperoleh konsensus dalam keluarga terhadap pelaksanaan peran yang ia terima. 
Problematika Keluarga dengan Pola Karir Ganda

Sehingga ada keterbukaan dalam keluarga tersebut.

\section{Hasil Temuan dan Analisis}

Selain secara klasifikasi pada beberapa kesulitan dan permasalahan di atas, ada beberapa temuan yang dapat diperoleh dari hasil identifikasi dan analisis terhadap keluarga dengan pola karir ganda di Wilayah Mangir, Sendangsari, Pajangan, Bantul yakni:

a. Pekerjaan menjadi salah
satu faktor
$\begin{aligned} & \text { utama } \\ & \text { mertimbangan }\end{aligned}$
$\begin{aligned} & \text { dalam } \\ & \text { keturunan dalam keluarga }\end{aligned}$
Maksud dari pernyataan ini
adalah pada tahap penentuan keturunan selain usia dan kesehatan ternyata ditemukan bahwa faktor pekerjaan dan kesibukan memang menjadi satu faktor yang melatarbelakangi sebuah keluarga untuk tidak ingin memiliki keinginan lagi. Ketika ayah dan ibu sama-sama bekerja dikatakan bahwa akan sangat repot jika memiliki anak lagi. Begitu pula dari pihak anak yang menyatakan bahwa di rumah sudah tidak pernah ada orang, apalagi jika memiliki adik lagi, maka hanya akan menjadi tugas tambahan bagi anak untuk mengasuh adik.
b. Masih
melekatnya
penempatan wanita pada stereotipe di bawah laki-laki
Hal ini dapat ditemukan pada pernyataan narasumber, meskipun secara tersurat mengatakan bahwa tidak masalah

membantu pekerjaan istri namun dengan beberapa pernyataan yang menyebutkan bahwa :

1) Pekerjaan di dapur adalah pekerjaan wanita

2) Dalam keluarga yang wajib bekerja sebenarnya laki-laki

3) Tidak merasa minder dengan istri yang bekerja karena gaji lebih besar suami

4) Tugas manajemen keuangan menjadi tugas wanita karena berhubungan dengan rumah tangga

Hal seperti ini sebenarnya menyiratkan sebuah prinsip yang masih melekat bahwa laki-laki tetap berada pada posisi di atas perempuan dalam sebuah keluarga. Ketidakadilan gender masih terlihat dalam hal ini seperti dalam analisis gender dan beban kerja menyatakan bahwa bias gender yang mengakibatkan beban kerja diperkuat dan disebabkan oleh adanya pandangan atau keyakinan di masyarakat bahwa pekerjaan yang dianggap masyarakat sebagai jenis "pekerjaan perempuan" seperti semua pekerjaan domestik (rumah tangga ${ }^{58}$. Sehingga dalam klasifikasi demikian dan dalam fakta yang terlihat dalam masyarakat terutama keluarga dengan pola karir ganda di Mangir, perilaku bias gender sebenarnya masih melekat terutama pada kaum laki-laki.

\footnotetext{
58 Farida Hanum, Diktat Sosiologi Gender, Yogyakarta : UNY, 2007, hlm 15.
} 


\section{E. Kesimpulan dan Saran \\ 1. Kesimpulan}

Keluarga dengan pola karir ganda merupakan keluarga yang terdiri atas ayah ibu yang samasama bekerja atau memiliki pekerjaan dan penghasilan. Mangir merupakan salah satu kawasan wilayah di Kelurahan Sendangsari, Kecamatan Pajangan, Kabupaten Bantul, Propinsi Daerah Istimewa Yogyakarta yang masih berada pada kawasan perdesaan dengan sistem kemasyarakatan tradisional yang masih melekat serta beberapa perubahan di dalamnya. Pada masa modern saat ini, masyarakat Mangir pun telah mengalami perkembangan dengan beberapa keluarga telah berjalan dengan pola karir ganda.

Berdasarkan penelitian yang dilakukan didapatkan beberapa kesimpulan bahwa:

a. Latar belakang keluarga dengan Pola Karir Ganda di Wilayah Mangir, Sendangsari, Pajangan, Bantul, Yogyakarta memilih Pola Karir Ganda adalah karena beberapa hal yakni ketidaksengajaan dan prinsip dalam hal keinginan untuk mendapatkan pasangan yang bekerja.

b. Problematika yang dialami keluarga dengan pola karir ganda di Mangir adalah pada beberapa hal yakni tidak dapat berpartisipasi dalam kegiatan sosial kemasyarakatan, keterbatasan kemampuan orang tua untuk mendampingi perkembangan proses belajar anak, pengeluaran tidak terduga terkait dengan sumbangan untuk kegiatan hajatan rekan di masyarakat dan di kantor, tidak dapat diselesaikannya pekerjaan rumah tangga dengan baik, aturan waktu bekerja setiap saat/ tidak menentu yang harus mengorbankan kebersamaan bersama keluarga, mis komunikasi untuk "hubungan" suami istri, krisis percaya diri terhadap peran seorang ibu, istri dan seorang pekerja, terbenturnya agenda pekerjaan di tempat kerja dengan kegiatan yang lain, pendampingan khusus untuk anak yang menyebabkan pekerjaan tidak maksimal, lelah atau stress terhadap padatnya pekerjaan, kurangnya kontrol orang tua yang menimbulkan permasalahan pada anak.

c. Berbagai problematika yang dialami keluarga dengan pola karir ganda di Wilayah Mangir, Sendangsari, Pajangan, Bantul diatasi dengan berbagai cara oleh masing-masing keluarga. Diantara beberapa cara tersebut adalah melalui komunikasi, menggunakan jasa pihak ketiga, membagi tugas atau pekerjaan rumah tangga, mendiamkan permasalahan, salah satu pihak mengalah, dan meminta saran kepada pihak lainnya.

d. Beberapa temuan yang dapat diidentifikasi dari karakteristik dan kehidupan keluarga dengan pola karir ganda di Wilayah Mangir, Sendangsari, 
Problematika Keluarga dengan Pola Karir Ganda

Pajangan, Bantul, Yogyakarta bahwa dalam sebuah keluarga dengan suami istri yang samasama bekerja atau pola karir ganda pekerjaan menjadi salah satu faktor utama yang menentukan keberadaan keturunan dalam keluarga dan masih melekatnya penempatan perempuan pada stereotipe di bawah kaum laki-laki.

\section{Saran}

Setelah peneliti melakukan penelitian tentang "Problematika Keluarga dengan Pola Karir Ganda di Wilayah Mangir, Sendangsari, Pajangan, Bantul, Yogyakarta" maka peneliti mengajukan berbagai saran sebagai berikut:

a. Setiap keluarga dengan pola karir ganda di Wilayah Mangir lebih memperhatikan fungsifungsi pokok keluarga agar tetap dapat terlaksana dengan baik demik kelangsungan hidup keluarga yang lebih harmonis.

b. Setiap keluarga dengan pola karir ganda di Wilayah Mangir dapat melakukan kontrol dengan maksimal terhadap perkembangan anak agar tidak mudah terbawa arus perubahan tanpa monitoring dari orang tua.

c. Setiap keluarga dengan pola karir ganda di Wilayah Mangir dapat mengatur dan menyesuaikan waktu antara pekerjaan, keluarga, dan masyarakat dengan baik.

d. Setiap pasangan yang akan membina rumah tangga dapat mempersiapkan dengan matang terhadap segala sesuatu yang berkaitan dengan kelangsungan hidup rumah tangga di masa mendatang.

\section{Daftar Pustaka}

Alsa, Asmadi. 2003. Pendekatan Kualitatif Kuantitatif serta Kombinasinya dalam Penelitian Psikologi. Yogyakarta: Pustaka Pelajar Offset.

Arikunto, Suharsimi. 1993. Prosedur Penelitian Suatu Pendekatan Praktis. Jakarta: Rineka Cipta.

Bachtiar, Wardi. 2006. Sosiologi Klasik dari Comte hingga Parsons. Bandung: Remaja Rosdakarya.

Damsar. 1997. Sosiologi Ekonomi. Jakarta: PT Raja Grafindo Persada.

Faisal, Sanapiah. 2005. Format-format Penelitian Sosial. Jakarta: Raja Grafindo Persada.

Idrus, Muhammad. 2007. Metode Penelitian Ilmu-Ilmu Sosial (Pendekatan Kualitatif dan Kuantitatif). Yogyakarta: UII Press.

Johnson, Doyle Paul. 1986. Teori Sosiologi Klasik dan Modern Jilid I. Jakarta: Gramedia. 1988. Teori Sosiologi Klasik dan Modern Jilid II. Jakarta: Gramedia.

J.S Badudu dan Sutan Muhammad Zain. 1996. Kamus Umum Bahasa 
| Nur Endah Januarti

Indonesia. Jakarta: Pustaka Sinar Harapan.

Khairuddin. 1985. Sosiologi Keluarga. Yogyakarta: Nur Cahaya.

K.J Veeger. 1986. Realitas Sosial. Jakarta: Gramedia. Moleong, Lexy J. 2006. Metodologi Penelitian Kualitatif. Bandung: Remaja Rosdakarya.

Parker, dkk. 1992. Sosiologi Industri. Jakarta: Rineka Cipta.

Rowatt, G, dkk. 1990. Bila Suami Istri Bekerja: The Two Career Marriage. Yogyakarta: Kanisius.

Salim, Agus. 2006. Teori dan Paradigma Penelitian Sosial. Yogyakarta: Tiara Wacana.

Soeharto, Bohar. 1989. Menyiapkan Penelitian dan Penulisan Karya Ilmiah (Skripsi-Thesis). Bandung: Penerbit Tarsito.

Soehartono, Irawan. 2004. Metode Penelitian Sosial. Bandung: Remaja Rosdakarya.

Soekanto, Soerjono.2004. Sosiologi Keluarga. Jakarta: Rineka Cipta.

Taneko, Soleman B. 1984. Struktur dan Proses Sosial, Suatu Pengantar Sosiologi Pembangunan. Jakarta: CV. Rajawali.

Tim Projotamansari. 2010. Ki Ageng Mangir Cikal Bakal Desa Tertua di
Bantul (Draft Buku). Yogyakarta: Yayasan Projotamansari.

Hanum, Farida. 2007. Diktat Mata Kuliah:Sosiologi Gender. Yogyakarta: Universitas Negeri Yogyakarta.

Sayekti, dkk. 1995. Hasil Penelitian: Problem-problem Keluarga Tenaga Akademik dan Administrasi IKIP Yogyakarta. Yogyakarta: UPBK IKIP Yogyakarta.

Hasti Santoso. 2009. Skripsi: Pengaruh Peran Ganda Wanita dan Kesejahteraan Keluarga terhadap Pendidikan Formal Anak di Desa Sidorejo Kecamatan Jatisrono Kabupaten Wonogiri. Yogyakarta: UNY.

Indria Laksmi Gamayanti. 2010. "Anak Mulai Belajar Perkembangan Diri, Usia 1-3 Tahun Harus Lebih Diperhatikan". Kedaulatan Rakyat, 10 Januari.

. 2010. "Facebook Bisa

Hambat Potensi Dasar Anak". Kedaulatan Rakyat, 31 Januari.

Wikipedia, Kata kunci: problem, 2010, Tersedia pada http://translate.googleusercontent.c om/2010/24/wikipedia-problem/.

Diakses tanggal 29 Januari 2010.

Nn, Problematika hidup orang dewasa, 2010, Tersedia pada http://www.google.com/2010/pro blematika -problematika hidup orang dewasa/. Diakses pada tanggal 29 Januari 2010 